Amasya Ilahiyat Dergisi - Amasya Theology Journal

ISSN 2667-7326 | e-ISSN 2667-6710

Haziran / June 2021, 16: 197-227

\title{
Cahiliye Dönemi Hanif Şairlerin Şiirlerine Tematik Bir Yaklaşım -Tevhid Anlayışı-
}

\author{
Ramazan MEŞE \\ Dr. Öğr. Üyesi, İnönü Üniversitesi, İlahiyat Fakültesi, \\ Arap Dili ve Belagatı Anabilim Dalı \\ Assistant Professor, İnonu University, Faculty of Theology, \\ Department of Arabic Language and al-Balagha \\ Malatya, Turkey \\ ramazan.mese@inonu.edu.tr \\ orcid.org/0000-0001-8524-7923
}

\section{Makale Bilgisi / Article Information}

Makale Türü / Article Types: Araştırma Makalesi / Research Article

Geliş Tarihi / Received: 15 Mart / March 2021

Kabul Tarihi / Accepted: 4 Mayıs / May 2021

Yayın Tarihi / Published: 30 Haziran / June 2021

Yayın Sezonu / Pub. Date Season: Haziran / June

Sayı / Issue: 16 Sayfa / Pages: 197-227

Atıf / Cite as: Meşe, Ramazan. “Cahiliye Dönemi Hanif Şairlerin Şiirlerine Tematik Bir Yaklaşım -Tevhid Anlayışı- [A Thematic Approach to The Poems of Hanif Poets in The Period of Jahiliyya -The Concept of oneness of God-]". Amasya Ilahiyat Dergisi-Amasya Theology Journal 16 (June 2021): 197-227.

https://doi.org/10.18498/amailad.895030.

İntihal / Plagiarism: Bu makale, en az iki hakem tarafından incelendi ve intihal içermediği teyit edildi. / This article has been reviewed by at least two referees and scanned via a plagiarism software.

Copyright ( ) Published by Amasya Üniversitesi, İlahiyat Fakültesi / Amasya University, Faculty of Theology, Amasya, 05100 Turkey. All rights reserved. https://dergipark.org.tr/amailad. 
198 | R. MEŞE / Cahiliye Dönemi Hanif Şairlerin Şiirlerine Tematik Bir Yaklaşım -Tevhid Anlayış1-

\section{A Thematic Approach to The Poems of Hanif Poets in The Period of Jahiliyya -The Concept of oneness of God-}

\section{Abstract}

The ancient Arabic poetry has an important place after the Qur'an and hadiths in revealing the belief and religious thought of the Arabs of the period of Jahiliyya. These poems inform us about the lives, religious thoughts and belief structures of the Arabs. In particular, the examination of poems dealing with religious issues is important in determining the religious thought of that period. In the period of Jahiliyya, those who avoided believing in idols and opposed some of the traditions of Jahiliyya and proclaimed that they are followers of Abraham's religion were called hanifs. They were people who believed in the oneness of God. They acted against the established culture of paganism and did not worship their deities. Some of the poets of the period of Jahiliyya were among those hanifs. In their poems, they dealt with monotheism among many religious themes and revealed that they had the belief of the oneness of God.

The most basic concept that gives Islamic belief its distinctive character is oneness of God. This concept is one of the important features characterizing the nature of human beings. For this reason, human beings have been expressing the truth of oneness since their creation. The Haniff poets of the period of Jahiliyya also expressed the truth of oneness of God in their poems. It is seen that some poets who did not worship the idols and who were opposed to the common religious belief of the day dealt with some important theological issues such as belief in the hereafter, belief in the day of reckoning, heaven and hell, in their poems. These poets have expressed, in their poems, God's unity and uniqueness, His being the absolute creator and the owner of the day of reckoning. In addition, they emphasized the wrongness of associating gods with Allah and the evil customs in that period.

In the poetry of hanif poets in the period of Jahiliyya, the most basic religious themes matter that comes to the forefront is the oneness of God. For, there are examples in the poetry of the period of Jahiliyya that Arabs believed in the existence of God and placed Him above the idols. In this respect, the theme of the oneness of God, with which the hanif poets dealt in their poems, is regarded as one of the important evidences showing that there was belief in God in that period. It seems that those poems that the hanif poets said about the oneness of God in that period had a parallel understanding with Islamic belief system. In addition, it is understood from the poems that the hanif poets did not act contrary 
R. MEŞE / A Thematic Approach to The Poems of Hanif Poets in The Period of Jahiliyya

-The Concept of oneness of God-I 199

to Islamic belief and practices. For, the unity of God, the mistake of associating partners with Him, that He is the owner of the earth and the sky, the sole owner and creator of all creatures, His being the owner of the religion and the day of judgment, and the fundamental emphasis of Islam on the oneness of God are expressed in those poems.

In this study, the poems of some hanif poets and their understanding of the oneness God in those poems are examined. These poets are Kuss b. Sâida al-Iyâdî, Zayd b. 'Amr al-Nufayl, Zuhayr b. Abî Sulmâ al-Muzanî, Varaqa b. Nawfal and Umayya b. Abî al-Salt. The fact that these hanif poets are mentioned commonly in the sources is the reason why they have been preferred to be examined in the present study. Apart from them, there undoubtedly were some poets who were called as hanif in some sources and emphasized the unity of God in their poems. However, in order not to exceed the limits of this study, only the five of them are going to be focused on and their poems containing the oneness of God are going to be examined. The above mentioned are going to be discussed chronologically. In the present study, firstly, I give information about the poetry of the period of Jahiliyya. Secondly, I go onto dealing with the concept of hanif in the given period. Finally, I discuss the above-mentioned poets and deal with some of their poems containing the oneness of God, after giving personal information about them.

Keywords: Arabic Language and Rhetoric, The Period of Jahiliyya, Hanîf, Hanîf Poets, Tawhîd (the oneness of God).

\section{Cahiliye Dönemi Hanif Şairlerin Şiirlerine Tematik Bir Yaklaşım -Tevhid Anlayışı-}

Öz

Cahiliye dönemi Araplarının inanç ve dini düşünce yapısı hakkında Kur'an ve hadislerden sonra eski Arap şiiri önemli bir yere sahiptir. Bu şiirler Arapların yaşantıları, dini anlayışları, inanç yapıları hakkında bilgi verir. Özellikle de dini konuları ele alan şiirlerin incelenmesi, o dönemin dini anlayışını tespit etmede önem arz eder. Cahiliye döneminde putlara inanmaktan uzak duran ve bazı Cahiliye adetlerine karşı çıkıp kendilerinin Hz. İbrahim'in dini üzerine olduklarını söyleyen kişilere hanif denilmiştir. Hanifler tevhid inancına sahip kişilerdi. Bunlar yerleşik kültür olan paganizme aykırı hareket etmişler ve onlara ibadet etmemişlerdir. Bu hanifler arasında Cahiliye döneminin bazı şairleri de 
200 | R. MEŞE / Cahiliye Dönemi Hanif Şairlerin Şiirlerine Tematik Bir Yaklaşım -Tevhid Anlayışıyer almıştır. Bu şairler şiirlerinde birçok dini temanın yanında tevhid konusunu da ele almışlar ve şiirlerinde tevhid inancına sahip olduklarını ortaya koymuşlardır.

İslam inancına ayırıcı vasfını kazandıran en temel anlayış tevhiddir. Bu anlayış insanoğlunun selim fıtratında bulunan önemli özelliklerden bir tanesidir. Bu sebeple insanoğlu yaratılışından bu yana tevhid hakikatini dile getirmekten kendini alamamıştır. Cahiliye dönemi hanif şairleri de tevhid hakikatini şiirlerinde dile getirmişlerdir. Özellikle puta tapmayan ve yaygın dini inanca muhalif bazı şairlerin şiirlerinde başta tevhid olmak üzere ahiret inancı, hesap gününe iman, cennet ve cehennem gibi itikadı meseleleri konu edindikleri görülmektedir. Bu şairler tevhid konusunda Allah'ın birliğini, eşinin ve benzerinin olmadığını, mutlak yaratıcı, hesap günü sahibi olduğunu şiirlerinde ifade etmişlerdir. Bunun yanında Allah'a şirk koşmanın ve Cahiliyedeki kötü adetlerin yanlışlığını da vurgulamışlardır.

Cahiliye döneminde hanif şairlerin söyledikleri şiirlerde ön plana çıkan en temel akidevî konu tevhiddir. Zira Cahiliye dönemi şiirinde Arapların Allah'ın varlığına inandıkları ve onları putlardan üstün tuttuklarına dair örnekler vardır. $\mathrm{Bu}$ açıdan hanif şairlerin şiirlerinde ele aldıkları tevhid konusu Cahiliye döneminde Allah inancının olduğunu gösteren önemli delillerden kabul edilir. $\mathrm{Bu}$ dönemde hanif şairlerin tevhid ile alakalı olarak söyledikleri bu şiirler İslam inanç sistemi ile paralel bir anlayışta olduğu görülür. Ayrıca hanif şairlerin İslam inanç ve muamelat sistemine aykırı bir davranış sergilemedikleri söz konusu şiirlerden anlaşılır. Zira Allah'ın birliği, O'na ortak koşmanın yanlışlığı, O'nun yerin ve göğün sahibi olduğu, bütün mahlûkatın tek sahibi ve yaratıcısı, din ve hesap günün sahibi olduğu gibi İslam'ın temel tevhid vurgusu bu şiirlerde dile getirilmiştir.

İşte bu çalışmada bazı hanif şairlerin şiirleri ve bu şiirlerindeki tevhid anlayışları üzerinde durulmuştur. Bu şairler Kuss b. Sâide el-İyâdî, Zeyd b. 'Amr en-Nüfeyl, Züheyr b. Ebî Sülmâ el-Müzenî, Varaka b. Nevfel ve Ümeyye b. Ebi's-Salt'tır. Kaynaklarda en çok bu hanif şairlerden bahsedilmesi bu şairlerin tercih edilmesinin sebebidir. Bunun dışında bazı kaynaklarda hanif olarak geçen ve şiirlerinde tevhidi vurgulayan şairlerin olduğu şüphesizdir. Ancak bu çalışmanın sınırlarının aşılmaması için ismi geçen beş şair ve tevhid ile alakalı şiirleri incelenmiştir. İsimleri verilen şairler ölüm sırasına göre ele alınmıştır.

Çalışmada öncelikle Cahiliye dönemi şiiri hakkında bilgi verilmiştir. Daha sonra hanif kavramı hakkında bilgi verilerek Cahiliye dönemi hanifliği ele alınmıştır. 
R. MEŞE / A Thematic Approach to The Poems of Hanif Poets in The Period of Jahiliyya -The Concept of oneness of God-I 201

Akabinde Cahiliye döneminde yaşamış olan hanif şairlerin meşhur olanlarından Kuss b. Sâide el-İyâdî, Zeyd b. 'Amr en-Nüfeyl, Züheyr b. Ebî Sülmâ el-Müzenî, Varaka b. Nevfel ve Ümeyye b. Ebi's-Salt sırayla ele alınarak haklarında bilgiler verildikten sonra tevhid ile alakalı söylemiş oldukları şiirlerinden bazıları incelenmiştir.

Anahtar Kelimeler: Arap Dili ve Belagatı, Cahiliye Dönemi, Haniflik, Hanif Şairler, Tevhid.

\section{Giriş}

İslâmî dönem ile öncesini birbirinden ayırmak için kullanılan Cahiliye ifadesi, karanlık kabul edebilecek bir döneme isim olmuştur. Zira bu dönem kabileler arası savaş, zulüm, zina, güç ve kudret gösterişi yapmak gibi insanın yaratılış gayesine aykırı olan pek çok özelliğin bulunduğu bir dönem olarak kabul edilmektedir.

Bu dönemde hayat ilkel toplumlardaki gibi sosyal, siyasal, dini ve entelektüel düzeyi bakımından gayet sade, basit ve sı ̆̆ bir yapıya sahipti. Grek toplumlarındaki gibi felsefi inançlara ve zengin mitolojik unsurlara, büyük tapınaklara sahip değildi. ${ }^{1}$ Yine bu dönemde Araplar arasında yıldızlara ve güneşe tapanlar vardı. Bunun yanında Hristiyanlık ve Yahudilik inancına sahip kişilerin bulunduğu bilinmektedir. Ancak en meşhur dini anlayış putperestlikti. Nitekim Kur'an'1 Kerim'de inandıkları putların isimleri zikredilmiştir.2 Yaygın inanış putperestlik olmasına rağmen Cahiliye şiirinde dini konulara ve puta tapıcılı̆̆a pek yer verilmemiştir. $\mathrm{Bu}$ durum ya o dönem şairlerinin dine önem vermemelerinden ya da İslam geldikten sonra bu şiirlerin rivayet edilmemesinden kaynaklanabilir. Birinci ihtimal ikinci ihtimale göre biraz zayıf kalmaktadır. Çünkü Cahiliye dönemi bazı şairlerin dini içerikli şiirleri elimize ulaşmıştır. Her ne kadar bu şiirlerde putperestlikten bahsedilmese de şairlerin dini önemsemedikleri anlamını çıkarmak doğru değildir. Dolayısıyla burada ikinci ihtimal daha güçlü durmaktadır. Zira yazıya İslam geldikten ve her yere yayıldıktan sonra geçildiği düşünüldüğünde o dönemde sözlü olarak aktarılan bu şiirlerin

\footnotetext{
1 Ahmed Hasan ez-Zeyyât, Târîhu'l-edebi'l-'Arabî (Kahire: Dâru Nahdâti Misr, ts.), 9.

2 Bk. en-Necm 53/19, Nûh 71/23, es-Saffât 37/125.
} 
Müslümanlar tarafından sözlü ya da yazılı olarak aktarılması gerekli görülmemiş olabilir.

Bunun yanında Cahiliye döneminden bize ulaşan bazı şiirlerde dini konulara yer verildiği bilinmektedir. Özellikle puta tapmayan ve yaygın dini inanca muhalif bazı şairlerin şiirlerinde başta tevhid olmak üzere ahiret inancl, hesap gününe iman, cennet ve cehennem vb. itikadî meseleleri konu edindikleri görülmektedir. Bunlar arasında hanif olarak bilinen bazı şairlerin de varlığı bilinmektedir. Allah'ın birliğine inanan hanifler puta tapmaya karşı çıkmakla birlikte Hz. İbrahim'in dinine inanırlar ve onu yeniden diriltecek bir peygamberin gönderileceğini söylerlerdi. Bu hanifler ortak bir dine inanmaz ve ortak bir ibadet şekilleri de yoktu.

İşte bu çalışmada söz konusu hanif şairlerin tevhid inancı ile alakalı söylemiş oldukları şiirleri ele alınacaktır. Cahiliye dönemi şiiri ve haniflik anlayışından bahsedildikten sonra Cahiliye dönemi hanif şairlerinden en meşhur olanları ve bunların tevhid ile ilgili söylemiş oldukları şiirleri incelenecektir.

\section{Cahiliye Dönemi Şiiri}

İslam'dan önceki dönem için Cahiliye ifadesi kullanılır. Bu dönem şiirine Cahiliye şiiri; bu dönemde yaşamış şairlere de Cahiliye şairi denir. ${ }^{3}$ İslâm geldikten sonra önem kazanmaya başlayan Cahiliye şiiri önceleri Kur'ân'daki garîb kelimelerin anlamının tespitinde kullanılmıştır. Buna bağlı olarak sözlü aktarıla gelen bu şiirleri ilk olarak Hammad er-Raviye (öl. 160/776) derleyerek yazıya geçirmiştir. ${ }^{4}$ Bunu takiben Mufaddal edDabbî (öl. 178/794) ve Asmâî (öl. 216/831) gibi pek çok dilci tarafından Cahiliye şiirleri toplanmış ve yazılı kültüre aktarılmıştır. ${ }^{5}$ Kur'ân'daki garip lafızların anlaşılması gayesiyle derlenen bu şiirler zamanla da Kur'ân ilimleri, dil, tarih, edebiyat vb. ilimlerde de kullanılagelmiştir.

Cahiliye şiiri tekellüften uzak olup anlatılmak istenen şey muhtasar bir şekilde anlatılır. Ağır bir dil kullanılmamıştır. Bugün karşılaşılan

3 Mustafa Fayda, "Cahiliye", Türkiye Diyanet Vakfı İslam Ansiklopedisi (İstanbul: TDV Yayınları, 1993), 7/17.

4 Ebû Abdillâh Muhammed b. Sellâm el-Cumahî, Tabakâti fuhûli'ş-şuâra, thk. Mahmud Muhammed Şâkir (Cidde: Dâru'l-Medenî, ts.), 1/48.

5 Kenan Demirayak - Sadi Çöğenli, Arap Edebiyatında Kaynaklar (Erzurum: Atatürk Üniversitesi Fen-Edebiyat Fakültesi Yayınları, 1994), 34-35. 
R. MEŞE / A Thematic Approach to The Poems of Hanif Poets in The Period of Jahiliyya -The Concept of oneness of God-I 203 yabancı kelimeler aradan uzun zaman geçmesinden kaynaklanmaktadır. Bu dönem şiirinde tevriye ve cinas sanatları da pek az kullanılmıştır. ${ }^{6}$

Cahiliye şiirinin zamanında yazılmaması ve sözlü olarak aktarılması, bu şiirler hakkında birtakım şüphelerin ortaya çıkmasına sebep olmuştur. ${ }^{7}$ Bu konuda oryantalistlerin büyük bir kısmı tarafından Cahiliye şiiri reddedilir. Onlara göre Cahiliye şiiri İslam'dan sonra ihdas edilmiştir. Bazıları ise bu şiirlerde geçen Allah lafızlarının yerine Lat, Uzza vb. put isimlerinin olduğunu daha sonra bu put isimleri Allah lafzı ile değiştirildiğini söylemiştir. Yine son dönem edebiyatçılardan olan Taha Hüseyn de oryantalistlerle aynı görüşü paylaşmaktır. ${ }^{8}$

Cahiliye şiirinin o dönemin dini yapısını yansıtıp yansıtmadığ 1 da tartışma konusu olmuştur. Bunun sebeplerinden bir tanesi ise konuyla ilgili en meşhur eserin sahibi olan Muhammed b. Sellâm el-Cumâhî'nin (öl. 231/845) Hz. Ömer (öl. 23/643) ve Ebu Amr b. el-`Alâ'ya (öl. 153/770) atfen söylediği Cahiliye nesri kadar olmasa da Cahiliye şiirinin büyük bir kısmının zayi olduğuna dair ifadesidir. ${ }^{9}$ Aynı şekilde Cahiliye şiirinin dönemin dini yapısına yeterince ışık tutmadığına dair ortak bir kanı söz konusudur.

\section{Cahiliye Döneminde Haniflik}

Hz. İbrahim'in tebliğ ettiği dinin temeli tevhide dayanıyordu. Zamanla Araplar arasında cehaletin de yaygınlaşması ile tevhid inancına putperestlik karışmıştır. İslam gelmeden önce iyice yaygınlaşan bu anlayışa bazıları karşı çıkmış ve bunlara hanif; temsil ettikleri anlayışa da haniflik denilmiştir. ${ }^{10}$

Hanif, h-n-f kelimesinden türemiştir. Sözlükte vücuttaki yapısal bozukluk, çarpık ayak gibi anlamları ifade eder. Ahnef b. Kays'a (öl.

6 Cemal Muhtar, "Cahiliye Devri Şiiri”, Doğu Dilleri [Ankara Üniversitesi Dil ve TarihCoğrafya Fakültesi Doğu Dilleri ve Edebiyatları Bölümü Dergisi] 1/1 (1964), 47.

7 Muhtar, "Cahiliye Devri Şiiri”, 47.

8 Bu konuda bk. Taha Hüseyn, Cahiliye Şiiri Üzerine, çev. Şaban Karataş (Ankara: Ankara Okulu Yayınları, 2003), 32-95.

9 İbn Sellâm el-Cumahî, Tabakâti fuhûli'ş-şuâra, 1/25; Mehmet Yalar, "Din Faktörü Işında Cahiliye Şiirine Bir Bakış”, Uludă̆ Üniversitesi İlahiyat Fakültesi Dergisi 15/2 (2006), 2425.

10 Bk. Şaban Kuzgun, "Hanif”, Türkiye Diyanet Vakfı İslam Ansiklopedisi (İstanbul: TDV Yayınlar1, 1997), 16/33-39. 
67/686) ayağındaki çarpıklıktan dolayı Ahnef ismi verilmiştir. Hanif ise bir şeye meyletmek, yönelmek anlamına gelir. Çoğulu "hunafâ" (الحنفاء)'dir. ${ }^{11}$

Cevherî'nin (öl. 400/1009) es-Sihah'ında (تحنّف الرجل) adam “hanif oldu" ifadesine karşıllk (اعتز الأصنام) "putlara tapmaktan vazgeçti" ifadesi kullanılır. ${ }^{12}$ Yine sözlüklerde bu kelime için (لعدوله عن الشرك) "Şirkten yüz çevirmesi sebebiyle" ifadesi kullanılır. ${ }^{13}$ Bu kelimenin anlamının bu şekilde olmasının sebebi bu şahısların yerleşik kültür olan paganizme aykırı hareket etmeleri ve onlara ibadet etmemeleridir. Hanif kelimesi terim olarak da Hz. İbrahim'in dini üzerine Mescid-i Haram'a yönelen Müslümana verilen isimdir. ${ }^{14}$

Cahiliye döneminde yerleşik kültüre (status quo) aykırı davrandiklarından hanif ya da haniflik kelimesinin olumsuz bir anlam ifade ettiği ortadadır. Ancak daha sonra İslam dini de Cahiliye dönemindeki yerleşik kültüre karşı çıkınca bu kelime İslam'dan sonra putlara inanmayan, Hz. İbrahim' in dinine mensubiyeti bildiren olumlu bir kelime olarak telakki edilmiştir. ${ }^{15}$

Cahiliye dönemi şiirlerinde haniflik olarak isimlendirilen akımın din olarak kabul edildiğine yönelik işaretler vardır. Mesela aşağıda da hakkında bilgi vereceğimiz hanif şairlerden Ümeyye b. Ebi's-Salt, bir

11 Halîl b. Ahmed el-Ferâhîdî, Kitâbu'l-'ayn, thk. Mehdî el-Mahzûmî - İbrahim esSamirrâî (Dâru ve Mektebetü'l-Hilâl, ts.), "hnf", 3/248; Ebû Muhammed b. Hasan b. Dureyd el-Ezdî, Cemheretü'l-lüğa, thk. Remzî Münîr Ba'lebekî (Beyrut: Dâru'l-i̇lmî Li'lMelâyîn, 1407/1987), “hfn”, 1/556; Ebû Nasr İsmail b. Hammâd el- Cevherî, Tâcu'l-lü̆ğa ve sihâhu'l-Arabiyye, thk. Ahmed Abdulgafûr Attâr (Beyrut: Dâru'l-i̇lmî Li'l-Melâyîn, 1407/1987), "hnf", 4/1347; Muhammed b. Mukerrem Cemâluddin İbn Manzûr, Lisânu'l- 'Arab, nşr. Dâru Sâdır (Beyrût: Dâru Sâdır, 1993), “hnf”, 9/56-57.

12 Cevherî, "hnf", 4/1347.

13 İbn Manzûr, "hnf", 9/58; Muhammed b. 'Abdurrezzâk el-Hüseynî Ebü'l-Feyd ezZebîdî, Tâcu'l-arûs min cevâhiri'l-kâmûs, thk. Mecmu'atün mine'l-Muhakkîkin (b.y.: Dâru'l-Hidâye, ts.), "hnf", 23/170.

14 Halîl b. Ahmed, “hnf", 3/248.

15 Bu konuda bk. Mehmet Mahfuz Söylemez, “Fil Hadisesinin Arap Yarımadasındaki Etkileri Üzerine Bir İnceleme", çev. Fuat Aydın, Kuran'daki Hanîf/ler ve Nasârâ Üzerine Araştırmalar (Ankara: Eskiyeni Yayınları, 2016), 369-382. 
R. MEŞE / A Thematic Approach to The Poems of Hanif Poets in The Period of Jahiliyya -The Concept of oneness of God-I 205 şiirinde hanif dininden başka her dinin kıyamet gününde Allah katından yalan olduğunu ifade etmiştir: ${ }^{16}$

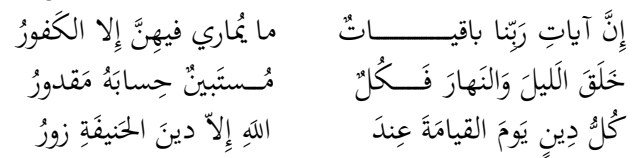

"Rabbimizin ayetleri kalıcıdır. Bunda ancak kafirler şüpheye düşer.

Gece ve gündüzü yaratmıştır ve bunların hepsi belli bir ölçüye göre ortaya çıkar.

Hanif dininden başka her din kıyamet günü Allah katında yalandır."

Bu beyitlerde Ümeyye Yüce Allah'ın varlığına ve yeryüzündeki delillerine işaret ederek hanifliği bir din olarak ifade etmekte ve diğer bütün dinlerden üstün tutmaktadır. Son beyitte Ümeyye b. Ebi's-Salt'ın hanif kelimesini kullanması önemlidir. Bunun yanında Cahiliyede hanif kelimesini kullanan şairlerin de varlığı da bilinmektedir. Bu da bazı müsteşriklerin bu kelimeyi $\mathrm{Hz}$. Peygamber'in uydurduğu savını çürütmektedir. ${ }^{17}$

Hanif olarak adlandırılan şahısların en meşhurları ise İbn İshak'ın (öl. 151/768) Sîre'sinde geçer. Bunlar Zeyd b. Amr, Osman b. Huveyris, Varaka b. Nevfel ve Ubeydullah b. Cahş'tır. Rivayete göre bunlar bir araya gelerek Kureyş'in dinini beğenmediklerini ifade etmişler kendilerine yeni bir din aradıklarını ilan etmişlerdir. Bunların üzerinde ittifak ettikleri bir din yoktur. ${ }^{18}$ Buna rağmen Arap Edebiyatı üzerinde yaptığı çalışmaları ile bilinen Luvîs Şeyho bütün hanif şairleri Hıristiyan kategorisine alır. ${ }^{19} \mathrm{Bu}$ görüşünü edebiyat tarihçisi Brockelmann tam bir hata olarak değerlendirmiştir. ${ }^{20}$ Bütün hanifleri Hıristiyan olarak değerlendirmek doğru bir çıkarım olamaz. Zira hanifler hakkında gelen

16 Ebü'l-Muzaffer Şemsüddîn Yûsuf b. Kizoğlu Sibt İbnü'l-Cevzî, Mir'âtü'z-zamân fî târîhi'l-a yân, thk. Muhammmed Berakat vd. (Dimeşk: Dâru'r-Risâleti'l-Alemiyye, $1434 / 2013), 2 / 521$.

17 Bu konuda bk. Hasan Küçükçopur, İslam Tarihinde Hanifler (Konya: Selçuk Üniversitesi, Sosyal Bilimler Enstitüsü, Yüksek Lisans Tezi, 1988), 67.

18 Bk. Ebû Abdillâh Muhammed b. İshâk b. el-Muttalibî, Sîretü İbn İshâk, thk. Sühey Zekkâr (Beyrut: Dâru'l-Fikr, 1398/1978), 115.

19 Bk. Luvis Şeyho, Şuarâu'n-nasrâniyye kable'l-İslâm (Beyrut: Dâru'l-Meşrik, 1991).

20 Carl Brockelmann, Târîhu'l-edebi'l-Arabî, çev. Abdulhalim en-Neccâr (Kahire: Dâru'lMe'ârif, ts.), 1/127. 
206 | R. MEŞE / Cahiliye Dönemi Hanif Şairlerin Şiirlerine Tematik Bir Yaklaşım -Tevhid Anlayışırivayetlere bakıldığında bütün haniflerin Hıristiyan olduklarına dair bir bilgi yoktur.

\section{Cahiliye Dönemi Hanif Şairlerin Şiirlerinde Tevhid}

İslam inancına ayırıcı vasfını kazandıran en temel anlayış tevhiddir. ${ }^{21} \mathrm{Bu}$ anlayış insanoğlunun selim fitratında bulunan önemli özelliklerden bir tanesidir. Nitekim Rum sûresi 30. ayette bu hakikat şöyle ifade edilmiştir: "Hakka yönelen biri olarak yüzünü dine, Allah'ın insanları üzerinde yarattı̆̆ fıtrata çevir. Allah'ın yaratmasında hiçbir değgiştirme yoktur. İşte bu dosdoğru dindir. Fakat insanların çoğu bilmezler." Bu hakikat Cahiliye döneminde de varlığı yadsınamaz bir gerçek olarak karşımıza çıkar. Cahiliye döneminde hâkim inanış putperestlik olmasına rağmen Cahiliye dönemi Arapları put ve putlara verdikleri adlardan daha üstün olarak Allah lafzını çoğu zaman kullanırlard $1 .{ }^{22}$ Bu dönemde Allah inancının mevcut olduğu Arapların dualarında "ya Allah" ve "Allahumme" tabirlerini kullanmalarından anlaşılır. Yine Allah lafzının çoğulunun olmaması, Allah için putlara kullandıkları sıfatlardan daha yüce sıfatlar kullanmaları, Allah adına yemin etmeleri ve çocuklarına "Abdullah" gibi isimler vermeleri Allah inancının Cahiliye döneminde varlığına delillerdir. ${ }^{23}$

Kur'ân'da putlar dişında yerin ve göğün yaratıcısının, yağmuru yağdıranın ve onunla toprağa can verenin Allah olduğunu Cahiliye dönemi müşriklerinin bildiği, ${ }^{24}$ zor zamanlarda O'na sığındıkları, ${ }^{25}$ en büyük yeminleri $\mathrm{O}^{\prime}$ na ettikleri ${ }^{26}$ ifade edilmiştir. Yine ürünlerinin bir kısmını Allah'a adına ayırmaları, ${ }^{27}$ melekleri Yüce Allah'ın kızları ${\text { saymalar }{ }^{28}}^{2}$ ve Allah için oğul ve kızlar isnat etmeleri ${ }^{29}$ Cahiliye döneminde Arapların Allah'ı tanıdıklarını gösterir.

21 Hasan Kaplan, "Bir İnanç Aşaması Olarak Haniflik", Çanakkale Onsekiz Mart Üniversitesi Illahiyat Fakültesi Dergisi 10 (2017), 8.

22 Cevâd Alî, el-Mufassal fî târîhi'l-'Arab kable'l-İslâm (b.y.: Dâru's-Sâkî, 1422/2001), 11/107.

23 Mustafa Çağrıcı, "Arap", Türkiye Diyanet Vakfi İslam Ansiklopedisi (İstanbul: TDV Yayınları, 1991), 3/316-317.

24 el-Ankebût 29/61, 63; Lokmân 31/25; ez-Zümer 39/38; ez-Zuhruf 43/9.

25 Yûnus 10/22; el-Furkân 25/13; el-Ankebût 29/65; Lokmân 31/32.

26 el-Mâide 5/53; el-En'âm 6/109; en-Nahl 16/38; en-Nûr 24/53.

27 el-En'âm 6/138.

28 en-Necm 53/21.

29 el-En'âm 6/100. 
R. MEŞE / A Thematic Approach to The Poems of Hanif Poets in The Period of Jahiliyya -The Concept of oneness of God-I 207

Cahiliye döneminde hanif şairlerin söyledikleri şiirlerde ön plana çıkan en temel akidevî konu tevhiddir. ${ }^{30}$ Zira Cahiliye dönemi şiirinde Arapların Allah'ın varlığına inandıkları ve onları putlardan üstün tuttuklarına dair örnekler vardır. Örneğin Cahiliye dönemi şairi Evs b. Hacer (öl. 620 m.) Allah'ın en yüce olduğunu şu beytiyle ifade etmiştir: ${ }^{31}$

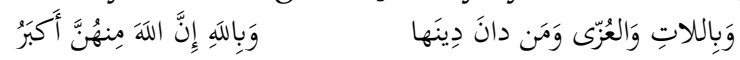

Lât', 'Uzzâ ve onlara ibadet eden kimselere yemin ederim, Allah'a da yemin ederim. Zira Allah, en büyüktür.

Kaynaklarda hanif olarak kabul edilecek kimseler hakkında herhangi bir standarttın olmaması, kimin hanif sayılacağı konusunu karmaşık bir hale getirmektedir. Cevâd Alî, rivayetlerden kaynaklanan bu karışıklığı gidermek için hanifleri, putlara tapmayan, tevhidi benimseyen, hayatlarını bu yönde idame eden, Hıristiyan ya da Yahudi olmayanlarla sınırlı tutulmasını önermiştir. ${ }^{32}$

Hanif şairlerin şiirlerinde ele aldıkları tevhid konusu Cahiliye döneminde Allah inancının olduğunu gösteren önemli delillerdendir. İşte $\mathrm{Bu}$ çalışmada bazı hanif şairlerin şiirleri ve bu şiirlerindeki tevhid anlayışları üzerinde durulacaktır. Bunlar: Kuss b. Sâide, Zeyd b. 'Amr, Züheyr b. Ebî Sülmâ, Varaka b. Nevfel, Ümeyye b. Ebi's-Salt'tır. Kaynaklarda en çok bu hanif şairlerden bahsedilmesi bu şairlerin tercih edilmesinin sebebidir. Bunun dişında bazı kaynaklarda hanif olarak geçen ve şiirlerinde tevhidi vurgulayan şairlerin olduğu şüphesizdir. Ancak bu çalışmanın sınırlarının aşılmaması için isimleri verilen şairlerin tevhid ile alakalı şiirleri ele alınacaktır. Söz konusu şairler ölüm sıralamasına göre ele alınarak incelenecektir.

30 İbrahim Ethem Polat, "Hanif Şairlerin Şiirlerinde Monoteist Yapı", Nüsha: Şarkiyat Araştırmaları Dergisi 1/1 (Bahar 2001), 124.

31 Dîvânu Evs b. Hacer, thk. Muhammed Yûsuf Necm (Beyrut: Dâru'l-Beyrût, 1400/1980), 36; Cevâd Alî, el-Mufassal fì târîhi'l-'Arab kable'l-İslâm, 11/234; Alî el-Cündî, Fî târîhi'lEdebi'l-Câhilî (b.y.: Mektebetü Dâru't-Türâs, 1412/1991), 189.

32 Cevâd Alî, el-Mufassal fì târîhi'l-'Arab kable'l-İslâm, 12/25. 
208 | R. MEŞE / Cahiliye Dönemi Hanif Şairlerin Şiirlerine Tematik Bir Yaklaşım -Tevhid Anlayışı-

\subsection{Kus b. Sâ‘ide el-İyâdî}

Kus b. Sâ'ide (öl. 600 m.), Hz. Muhammed'e risâlet gelmeden önce yaşamış, adı hanifler arasında zikredilen şair ve hatiplerdendir. ${ }^{33}$ Arapların şair ve hâkimlerinden olan Kus b. Sâ'ide, belagat ve fesahati ile meşhur birisidir. Tarihçilerin ifadesine göre Kus b. Sâ'ide uzun süre yaşamış muammarundan kabul edilen bir kişidir. Yaşı hakkında farklı rakamlar verilmekle beraber ölümünün bi'setten az öncesinde olduğu konusunda hemfikirdirler. Hanif şairlerin en meşhuru kabul edilen Kus b. Sâ'ide öldükten sonra dirilmeye inandığı, tevhid inancına sahip olduğu, Allah'a ibadete çağırdığı ve bir peygamberin geleceğini bildiği rivayet edilir. ${ }^{34}$ Kullandığ 1 ifadeler az, öz ve secili ifadeler olması onu Araplar arasında meşhur kılmıştır. ${ }^{35}$ Mektuplarda yer alan (من فلان إلى فلان) "min fülân ilâ fülân" ifadesi ile (أما بعد) "ammâ ba'dü" şeklindeki ifadeyi ilk defa kullandığı rivayet edilir. ${ }^{36}$ Ayrıca hutbe okurken yüksek yere çıkılması, kılıç veya asâya dayanılması gibi adetlerin onunla başladığı nakledilir. ${ }^{37}$

Hz. Peygamber'in Kus b. Sâ'ide'yi Ukâz panayırında okuduğu hutbede tevhid inancını vurgulamasından dolayı beğendiği rivayet edilir. ${ }^{38}$ Kus b. Sa'îde'nin kabilesi Hz. Peygamber'e gelip İslam'a girdiklerinde Hz. Peygamber onlar arasında Kus'un olup olmadığını sormuştur. Geçen sene onun öldüğünü söylediklerinde Hz. Peygamber (s.a.v) onu Ukaz panayırında kırmızı devesinin üzerinde halka hutbe okurken gördügünnü söylemiştir. ${ }^{39}$ Bu hutbeyi ezbere bilmediğini ve onu

33 Mehmet Ali Kapar, “Kus. b. Sâ'ide”, Türkiye Diyanet Vakfı İslam Ansiklopedisi (Ankara: TDV Yayınları, 2002), 26/460.

34 Ebü'l-Fidâ' İmâdüddîn b. Kesîr el-Kaysî el-Kureşî, el-Bidâye ve'n-nihâye, thk. Alî Şî̂î (Beyrut: Dâru İhyâi't-Türâsi'l-Arabî, 1408/1988), 2/292.

35 Ebû Abbas Ahmed b. Abdulmü'min eş-Şüreysî, Şerhu makâmatı'l-Harîrî (Beyrut: Dâru'l-Kütübi'l-İlmiyye, 1427/2006), 3/195.

36 Ebû Hilâl el-Hasen b. Abdillâh b. Sehl el-'Askerî, el-Evâil, nşr. Dâru'l-Beşîr (Tanta: Dâru'l-Beşîr, 1408/1987), 68.

37 Şüreysî, Şerhu makâmatı'l-Harîrî, 3/196; Kapar, “Kus. b. Sâ'ide”, 26/460.

38 Kapar, “Kus. b. Sâ'ide”, 26/460.

39 Ebû Osmân Bahr b. Mahbûb el-Câhiz, el-Beyân ve't-Tebyîn, nşr. Daru'1-Kütübi'lİlmiyye (Beyrut: Daru'l-Kütübi'l-İlmiyye, 1423/2002), 1/253; Şüreysî, Şerhu makâmatı'lHarîrî, 3/196; Ebû Muhammed Cemâlüddîn Abdülmelik b. Hişâm el-Meâfirî, et-Tîcân 
R. MEŞE / A Thematic Approach to The Poems of Hanif Poets in The Period of Jahiliyya -The Concept of oneness of God-I 209 ezbere bilen birinin olup olmadığını sormuştur. O esnada Hz. Ebubekir

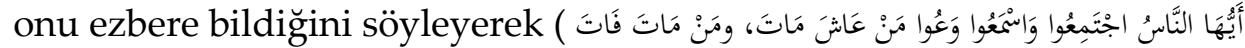
... Ey insanlar! Geliniz, dinleyiniz ve belleyiniz. Yaşayan ölür. Ölen geçicidir. Olacak olan her şey olur. Gökte haber yerde ibretler vardır"40 cümleleriyle başlayan meşhur hutbeyi okumuştur. Hz. Peygamber de Kus hakkinda "Allah Kus'a rahmet etsin. Ben onun kıyamet gününde ayrı bir ümmet olacă̆ını ümit ederim" buyurduğu rivayet edilir. ${ }^{41}$

Kus b. Sâ'ide'nin dini inanışı hakkında bazı kaynaklarda farklı görüşler olsa da genel kanı onun hanif anlayışına sahip olduğudur. Zira onun hutbeleri ve şiirleri incelendiğinde insanlara tevhidi anlattı̆̆ı ve bunun yanında haniflerdeki özelliklerin onda da olduğu görülür.

Kus b. Sâ'ide'nin aşağıdaki beyitleri dini içerikli olup onun tevhid anlayışına sahip olduğuna işaret etmiştir:42

$$
\begin{aligned}
& \text { كُلُّهُمْ في الصَّعِيد يَوما مَزَارُ }
\end{aligned}
$$

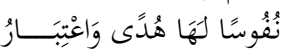

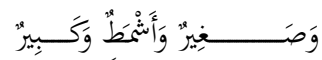

$$
\begin{aligned}
& \text { فالَّذِي قَذْ ذَكَرْتُ دَلَّ عَلْى اللَّهِ }
\end{aligned}
$$

"Küçük, karışık olan ve büyük hepsi bir gün mezar olur.

Benim bu söylediklerim hidayete ermiş ve ibret alan kimseler için, Allah'a giden yolu gösterir."

$\mathrm{Bu}$ beyitlerde Kus b. Sâ'ide ölüm gerçeğinin herkes için geçerli olduğunu vurguladiktan sonra bunun karşısında kimsenin duramayacağını ifade etmiştir. Daha sonra bu söylediklerinin Allah'a götüren bir yol olduğunu ifade etmiştir. Özellikle son beyitte Allah lafzını kullanması, Kus'un tevhid anlayışına sahip olduğuna işarettir. Bu şiiri ve onun hakkındaki rivayetler onun muvahhid olduğu konusunda ortak bir kanının oluşmasını sağlamıştır.

fì mülûki Himyer, thk. Merkezü'd-Dirâsât ve'l-Ebhâsı'l-Yemeniyye (San'â: Merkezü'dDirâsât ve'l-Ebhâsı'l-Yemeniyye, 1347/1928), 125.

40 Şüreysî, Şerhu makâmatı'l-Harîrî, 3/196.

41 Şeyho, Şuarâu'n-nasrâniyye kable'l-İslâm, 212.

42 İbn Kesîr, el-Bidâye ve'n-nihâye, 2/292. 
210 | R. MEŞE / Cahiliye Dönemi Hanif Şairlerin Şiirlerine Tematik Bir Yaklaşım -Tevhid Anlayışı-

\subsection{Zeyd b. Amr b. Nufeyl}

Zeyd b. Amr (öl. 605 m.) Hz. Ömer'in amcasının oğludur. ${ }^{43}$ Mekke'de meşhur bir ailenin çocuğu olup putlara ibadet etmemiştir. Tevhid inancı için bir arayışa girmiş, Hıristiyanlık ve Yahudilik dinlerini araştırmış ancak onları benimsemeyerek İbrâhim'in rabbine ibadet ettiğini ifade etmiştir. ${ }^{44}$ Zeyd b. Amr, içkiden, zinadan, boğazlanmadan kesilen hayvan eti yemekten ve putlara kurban kesmekten uzak duran dönemin aydın şahsiyetlerinden birisidir. ${ }^{45}$ Kureyşlilerin putlarını ilk olarak eleştiren ve bu sebeple Kureyşliler tarafından eziyet edilerek öldürülen Zeyd b. Amr, haniflerin en hayırlısı olarak kabul edilmiş ve kendisine "muvahhidu'l cahiliyye" (Cahiliye tevhidçisi) ismi verilmiştir. ${ }^{46}$ Dolayısıyla Zeyd İslam'dan önce Haniflik anlayışının önemli şahsiyetlerinden birisi olarak kabul edilir. ${ }^{47}$

Zeyd b. Amr, Hz. İbrahim'in dinine sahip olduğunu şöyle ifade ederdi: "Allah'ım! Şahit ol ki ben İbrahim'in dinindenim. Ey Allah'ım, ey İbrahim'in ilâhı, dinim İbrahim'in dinidir."48 Yine onun hakkında yapılan bir rivayete göre Zeyd, "Allah'ım, eğer ibadetin hangi şeklinin sana daha sevimli geldiğini bilseydim o şekilde sana ibadet ederdim. Fakat ben bunu bilmiyorum" diyerek secdeye kapanırd1. ${ }^{49}$

Zeyd b. Amr Cahiliye dönemine ait pek çok uygulamaya karşı çıkmış ve Cahiliye adetlerinden uzak durmuştur. Zinaya karşı insanları uyarmış, kız çocukları diri diri toprağa gömenlere engel olmaya çalışmıştır. ${ }^{50} \mathrm{~Hz}$. İbrahim' in anlayışı üzere olan Zeyd b. Amr'ın oğlu Said

43 Ebü'l-Kâsım Alî b. el-Hasen b. Hibetillâh İbn Asâkir, Târîhu Dımaşk, thk. 'Amr b. Ğarâme el-Ümeyrî (b.y.: Dâru'l-Fikr, 1415/1995), 19/498.

44 İbn Asâkir, Târîhu Dımaşk, 19/495.

45 İbn Kesîr, el-Bidâye ve'n-nihâye, 2/296.

46 Hamdân Zehrânî, Edebu'l-Hanefiyye fì Asri'l-Cahilî (Mekke: Câmiatu Ümmi'l-Kurâ, Kulliyeti Lügati'l-Arabiyye ve Âdâbıha, Doktora Tezi, 1406/1985), 100.

47 Bu konuda bk. Halit Özkan, “Zeyd b. Amr”, Türkiye Diyanet Vakfi İslam Ansiklopedisi (İstanbul: TDV Yayınları, 2013), 44/316; Recep Erkocaaslan, “Haniflerden Zeyd b. Amr b. Nüfeyl'in Hayatı ve Şahsiyeti”, Amasya İlahiyat Dergisi 15 (Aralık 2020), 421-451.

48 Ebû Abdillâh Şemsüddîn Muhammed b. Ahmed b. Osmân ez-Zehebî, Târihü'l-İslam ve vefeyâtü'l-meşâhiri'l-a'lâm, thk. Beşşâr Avvâd Ma'rûf (b.y.: Dâru'l-Ğarbi'l-İslâmî, 1424/2003) 1/518; İbn Kesîr, el-Bidâye ve'n-nihâye, 2/296.

49 Zehebî, Târihü'l-İslam ve vefeyâtü'l-meşâhiri'l-a'lâm, 1/520.

50 İbnü'l-Cevzî, Mir'âtü'z-zamân fî târîhi'l-a yân, 3/88. 
R. MEŞE / A Thematic Approach to The Poems of Hanif Poets in The Period of Jahiliyya -The Concept of oneness of God-I 211

ile Hz. Ömer, Hz. Peygamber'e gelerek Zeyd için bağışlanma dilemesini istemişlerdir. Hz. Peygamber bunu kabul ederek ve Zeyd hakkında "o tek başına bir ümmet olarak haşredilecektir" cevabını verdiği rivayet edilir. ${ }^{51} \mathrm{~Hz}$. Peygamber'in bu sözleri Zeyd ve onun gibi muvahhidler, sahabe kabul edilmedikleri halde, sahabeyi anlatan bazı kitaplarda yer almışlardır. ${ }^{52}$

Zeyd b. Amr'ın hanif anlayışına mensup olduğu ve tevhid inancına sahip olduğuna dair kaynaklarda ortak bir kanı olduğu aşikârdır. Onun, tevhid anlayışını insanlara anlattığı ve bu durumu şiirlerinde dile getirdiği elimize ulaşan şiirlerle sabittir. Nitekim Zeyd b. Amr şu kasidesinde tevhid inancının temel dinamiklerini ortaya koymaktadır: ${ }^{53}$
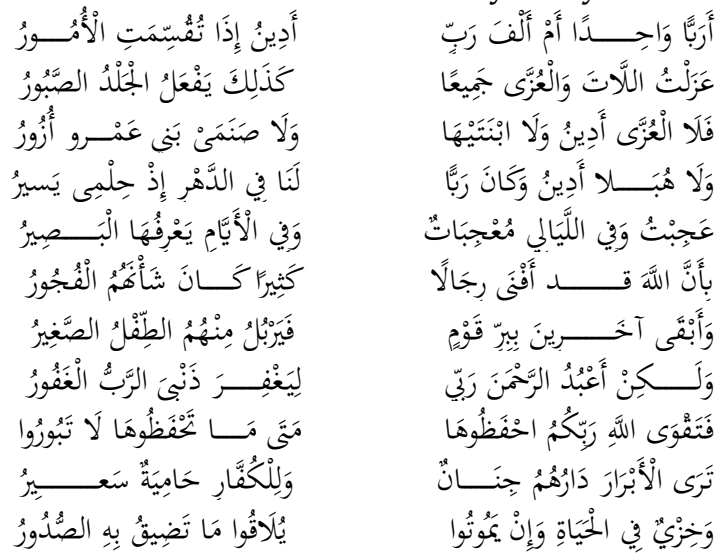

"İşler taksim edildiğinde bir rabbe mi yoksa bin rabbe mi ibadet edeyim.

Lât ve 'Uzza'yı hepsini terk ettim, yiğit ve sabırlı kişi aynen böyle yapar.

Ne 'Uzza'ya ne de onun iki kızına ibadet ederim. Ne de Benî Amr'ın iki putunu ziyaret ederim.

Aklımın henüz yetmediği çocukluğumda bize rabb olan Hübel'e de ibadet etmem.

Şaşırdım. Gecede ve gündüzde görenler için şaşılacak şeyler vardır.

51 Ebü'l-Hasen İzzüddîn İbnü'l-Esîr eş-Şeybânî el-Cezerî, Üsdü'l-ğâabe fî ma'rifeti's-sahâbe, thk. Alî Muhammed Mu'avved - Adil Ahmed Abdulmevcûd (Beyrut: Dâru'l-Kütübi'lİlmiyye, 1415/1994), 2/368.

52 Özkan, "Zeyd b. Amr”, 44/317.

53 Eysem Abbâs el-Kaysî, "Zeyd b. Amr b. Nufeyl Hayâtuh ve mâ Tebkâ min Şi'rih", Mecelletu'l-Mevrid 29/4, 90-91. Bu şiir farklı kaynaklar bazı ifadelerdeki değişiklikler de rivayet edilmiştir. Bk. İbn Asâkir, Târîhu Dımaşk, 19/514. 
212 | R. MEŞE / Cahiliye Dönemi Hanif Şairlerin Şiirlerine Tematik Bir Yaklaşım -Tevhid Anlayışı-

(Bilmez misin) Allah, işi kötülük olan birçok kişiyi yok etti.

Küçük çocuklar da büyüsün diye bir kavmin iyi olanlarını bıraktı.

Fakat çok bağııslayıcı olan Rab, günahlarımı bağışlasın diye sadece Rabbim Rahman'a ibadet ederim.

Allah'a karşı olan takvanızı muhafaza edin. Onu muhafaza edenseniz helak olmazsiniz.

Iyilerin yurdunu cennet olduğunu görürsün. Kâfirlerin ise yakıcı cehennem.

Onlar dünyada rezillerdir. Öldüklerinde göğ̈̈slerini sıkıp daraltan azapla karşılaşırlar."

$\mathrm{Bu}$ kasidenin ibareleri kaynaklarda farklı olsa da hepsi aynı anlamları içermektedir. Kasidede Zeyd b. Amr'ın tevhid inancını benimsediği açıkça ortadadır. Kavminin ve atalarının inandıkları putlara inanmadığını ifade etmiş ve Allah'ın bağışlayıcı ve merhametli yönünü dile getirerek Allah'a ibadet etmeye ve ona karşı takvalı olmaya çağırmıştır. Birinci beyitte tek bir rabbe inanmayı vurgulaması, sonraki üç beyitte Cahiliyenin meşhur putlarına ibadet etmediğini ifade etmesi ve diğer beyitler Allah'ın gücünden, bağışlayıcı olmasından cennet ve azaptan bahsetmesi onun bir olan Allah'a inandığını gösterir.

Bir başka şiirinde ise Zeyd b. Amr tek olan yaratıcıya teslim olduğunu ve ona yöneldiğini şöyle ifade etmiştir: ${ }^{54}$

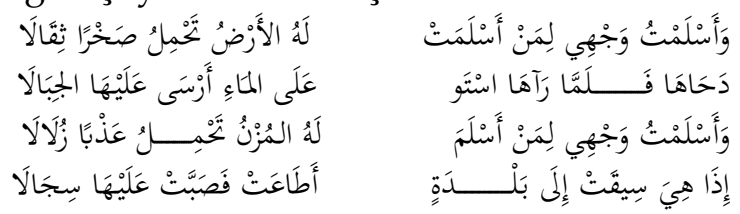

"A $\breve{g ̆ r}$ kayalar taşıyan yerin teslim olduğu zata bütün benliğimle teslim oldum.

Suyun üzerine durduğunu görünce üzerine dağları sabit kıldı ve dağlarla onları ă̆ırlaştırdı.

Tatl ve saf suları taşıyan bulutların teslim olduğu zata bütün benliğimle teslim oldum.

Bir de bakarsin ki o bulutlar, bir beldeye sürüklendiğinde, boyun eğip suların döküvermişler."

54 Cemâluddîn Ebu'l-Ferec İbnü'l-Cevzî, el-Muntazam fî târîhi'l-umem ve'l-mulûk, thk. Muhammed Abdulkadir Atâ - Mustafa Abdulkadir Atâ (Beyrut: Dâru'l-Kütübi'lİlmiyye, 1412/1992), 2/331. 
R. MEŞE / A Thematic Approach to The Poems of Hanif Poets in The Period of Jahiliyya -The Concept of oneness of God-I 213

Yine bu beyitlere şair Allah'a teslim olduğunu vurgularken aslında bütün kâinatın da ona teslim olduğunu ifade etmiştir.

Bir başka şiirinde ise Zeyd $b$. Amr'ın Allah inancı şu beyitlerde ortaya çıkmaktadır: ${ }^{55}$
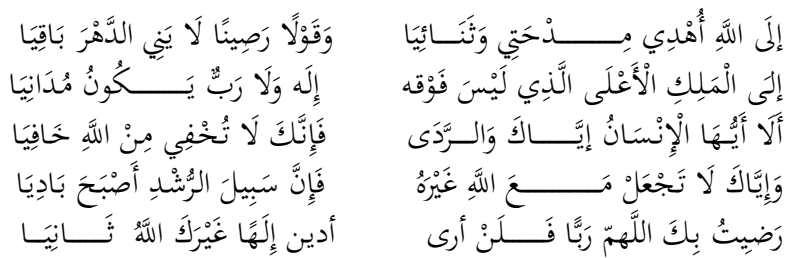

"Zamanın eskitmeyeceği muhkem sözlerle Allah'a övgü ve medihlerimi sunuyorum.

Ondan daha üstün ne bir rab ne de bir ilah olan en yüce Melike.

Ey insan! Ölüme karşı dikkatli ol! Sen (ölüm hakikati geldiğinde) Allah'tan hiçbir şeyi gizleyemezsin.

Sakın Allah'a ortak koşma! Zira doğru yol apaçık görünür oldu.

Ey Allah'ım! Rab olarak senden hoşnut oldum. Senden başka ikinci bir rabbe ibadet etmem."

Şair 18 beyitten oluşan kasidesinin bu beş beytinde bütün övgülerini Yüce Allah'a armağan ettiğini ve ondan başka ne bir ilahın ne de bir rabbin olabileceğini vurgulamaktır. Ayrıca ölüm gerçeğini hatırlatan şair burada ölümden korkmaktan çok ölümden sonra amellerin gizli kalmayacağı günden ve hesap gününden korkulmasına işaret etmektedir. Yine Allah'a karşı şirk koşulmamasını ifade ederken de asıl hakikatin zaten ortada olduğuna işaret etmiştir. Son olarak da Allah'tan başka kimseye ibadet etmeyeceğini vurgulamıştır. İbn Hişâm (öl. 218/833) bu beyitlerin bir kısmının Ümeyye b. Salt'a ait olduğunu ifade etmişse de genel olarak kaynaklarda söz konusu kaside Zeyd b. Amr'a nispet edilir. ${ }^{56}$

\subsection{Züheyr b. Ebî Sülmâ el-Muzenî}

Züheyr b. Ebî Sülmâ (öl. 609 m.), Cahiliye devrinin önde gelen muallaka şairlerindendir. Babasının kabilesi olan Müzeyne kabilesine

55 Ebû Muhammed Cemâlüddîn Abdülmelik b. Hişâm el-Meâfirî, es-Sîretü'n-nebeviyye, thk. Mustafa es-Sekkâ vd. (Kahire: Şirketü ve Matbatü Mustafa, 1375/1955), 1/227-228; Kaysî, "Zeyd b. Amr b. Nufeyl Hayâtuh ve mâ Tebkâ min Şi'rih", 91.

56 İbn Hişâm, es-Sîretü'n-nebeviyye, 1/227. 
mensuptur. ${ }^{57}$ Bisetten bir sene önce miladi 609 yllında vefat etmiştir. ${ }^{58}$ Meşhur Kasîde-i Bürde'yi (Banet Suad) yazan sahabe şair Ka'b b. Züheyr (öl. 24/645), Züheyr b. Ebî Sülmâ'nın oğludur. ${ }^{59}$ İyi bir ahlaka sahip olan Züheyr, Hz. Peygamber'in tebliğinden önce tevhid ve hak din hakkında şiirler yazan bir şairdir. Hanif grubunda yer alır, Allah'a ve ahiret gününe inanird1. ${ }^{60}$

Züheyr, İslam öncesi şairleri arasında önemli bir yere sahip olup birinci tabakada ismi zikredilir. ${ }^{61}$ Muallaka şairlerinden İmrü̈'l-Kays (öl. 540 m.), Nabiğa (öl. 604 m.) ve Züheyr' in Cahiliye dönemi üç büyük şairi olduğu rivayet edilir. ${ }^{62} \mathrm{~Hz}$. Ömer' in Züheyr'i "insanlar arasında en şair olanı" şeklinde övdügü rivayet edilir. ${ }^{63}$ Züheyr kasidelerini yazarken büyük özen gösterirdi. Bir kaside yazıp insanlara sunması bir yılı bulurdu. Bu sebeple onun kasidelerine "havliyyâtü Züheyr" (Züheyr'in yıllıkları) denilmiş ve bir darbımesel haline gelmiştir. ${ }^{64}$

Züheyr b. Ebî Sülmâ'nın şiirlerinde hikmet teması ön plana çıkar. ${ }^{65}$ Bunun yanında dini motifleri şiirlerinde çokça ele almıştır. Şiirleri incelendiğinde tevhidi vurgulayan birçok beyitle karşılamak mümkündür. Yine şiirlerinde ahiret, hesap, ceza, sevap, cennetcehennem, amel defteri gibi dini ifadeler de kullanılır. ${ }^{66}$

57 Ebû Muhammed Abdullah b. Müslim b. Kuteybe ed-Dîneverî, eş-Şi 'ru ve'ş-Şu 'arâ, nşr. Dâru'l-Hadîs (Kahire: Dâru'l-Hadîs, 1423/2002), 1/137; Ebû Abdillâh Hüseyn b. Ahmed ez-Zevzenî, Şerhu'l-muallakatı's-seb 'a, nşr. Dâru İhyâi't-Türâsi'l-Arabî (b.y.: Dâru İhyâi't-Türâsi'l-Arabî, 1423/2002), 121; Şevkî Dayf, Târîhu'l-edebi'l-Arabî (Misır: Dâru'l-Me'ârif, 1995), 1/300.

58 Mustafâ Sâdık er-Râfi'î, Târîhu âdâbi'l-Arab (b.y.: Dâru'l-Kitâbi'l-Arabî, ts.), 3/157.

59 Zevzenî, Şerhu'l-muallakatı's-seb 'a, 122.

60 Süleyman Tülücü, "Züheyr b. Ebî Sülmâ”, Türkiye Diyanet Vakfi İslam Ansiklopedisi (İstanbul: TDV Yayınları, 2013), 44/540.

61 İbn Sellâm el-Cumahî, Tabakâti fuhûli'ş-şuâra, 1/51; İmruü'1-Kays b. Hucr b. el-Hâris elKindî, Divânu Imrü̈'l-Kays, thk. Abdurrahman Mustâvî (Beyrut: Dâru'l-Ma'rife, 1425/2004), 11.

62 Râfi'î, Târîhu âdâbi'l-Arab, 3/156.

63 İbn Kuteybe, eş-Şi'ru ve'ş-Şu 'arâ, 1/137; Ebu'l-Abbâs Sa'leb, Şerhu şi'ri Züheyr b. Eb̂̂ Sülmâ, thk. Fahreddîn Kabâve (Dımeşk: Matba'atü'l-Ğûsânî, 2008), 201.

64 Zevzenî, Şerhu'l-muallakatı's-seb 'a, 122.

65 Dayf, Târîhu'l-edebi'l-Arabî, 1/307.

66 Bk. Sa'leb, Şerhu şi'ri Züheyr b. Eb̂̂ Sülmâ, 13-283. 
R. MEŞE / A Thematic Approach to The Poems of Hanif Poets in The Period of Jahiliyya -The Concept of oneness of God-I 215

Züheyr'in şiirlerde putperestlik izlerine rastlanmamaktadır. Yahudilikten etkilenmediği de bilinen bir gerçektir. ${ }^{67}$ Ancak onun Hristiyanlıktan etkilendiği de ifade etmiştir. ${ }^{68}$

Züheyr'in şiirlerine bakılınca her ne kadar İslami döneme yetişmemişse de tevhid inancına sahip olduğu kolaylıkla anlaşılabilir. Zira divanı incelendiğinde 13 yerde Allah lafzını kullandığı görülür. Ayrıca şiirlerinde birçok dini motife yer vermiştir. ${ }^{69}$

Züheyr'in şiirlerindeki genel havaya bakılınca onun Allah'a ve ahirete inandığ ${ }^{\prime}$ sonucuna varılabilir..$^{70}$ Ebû Ubeyde'den nakledilen bir rivayete göre Züheyr şöyle diyordu: "Ĕ̆er ayıplamasaydınız, ölmelerinden sonra şu şeyleri diriltecek olan (Allah'a) secde ederdim." "71 Mesela onun şu beyitleri Allah'a olan inancına işaret etmektedir: ${ }^{72}$

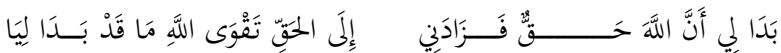

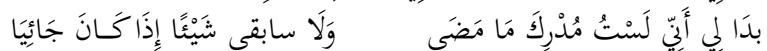

"Allah'ın Hak olduğu bana tecelli oldu. Bana bu tecelli olan, Allah'a karşı takvami arttıriyor.

Anladım ki geçmiş olana ulaşma imkânım olmadı̆̆ı gibi gelenin de önüne geçemem."

Züheyr bazı hakikatlerin farkına varmış ve şiirlerine de bunu yansitmıştır. Mesela ölümden sonra bir hesap günü olduğunu, içimizde olan şeyleri Allah'ın bildiğini ve bunlar hakkında insanın sorguya çekileceğini şöyle ifade etmiştir: ${ }^{73}$

67 Bu konuda bk. Süleyman Tülücü, “Cahiliye Devri Şairlerden Züheyr'in Dini İnancı ve Şiirlerinde Dini İzler", Diyanet Dergisi 25/2 (1989), 4-5.

68 Zevzenî, Şerhu'l-muallakatı's-seb 'a, 128.

69 Tülücü, "Cahiliye Devri Şairlerden Züheyr'in Dini İnancı ve Şiirlerinde Dini İzler", 8.

70 Kaysî, "Zeyd b. Amr b. Nufeyl Hayâtuh ve mâ Tebkâ min Şi' rih", 88.

71 Ebû Zeyd Muhammed b. Ebi'l-Hattâb el-Kurâşî, Cemheretü eş'âri'l-Arab, thk. Alî Muhammed el-Becâdî (b.y.: Nahdatü Misr Li'-tibâ'a ve'n-Neşr ve't-Tevzî̀', ts.) 70.

72 Sa'leb, Şerhu şi'ri Züheyr b. Ebî Sülmâ, 208-209; Muhammed b. Aydemir el-Musta'sımî, ed-Dürrü'l-ferîd ve beytü'l-kasîd, thk. Kâmil Selmân el-Cebûrî (Beyrut: Dâru'l-Kütübi'lİlmiyye, 1436/2015), 3/281.

73 Sa'leb, Şerhu şi'ri Züheyr b. Eb̂̂ Sülmâ, 26; Ebü’l-Haccâc Yûsuf b. Süleymân b. Îsâ elA'lem eş-Şentemerî en-Nahvî, Şerhu Dîvâni Zuheyr b. Eb̂̂ Sulmâ, thk. Muhammed Bedruddin Ebî Firâs (Misır: Matbaatü'1- Hamidiyye, 1323/1905), 86; Zevzenî, Şerhu'lmuallakatı's-seb 'a, 128; Dayf, Târîhu'l-edebi'l-Arabî, 1/303. 
216 | R. MEŞE / Cahiliye Dönemi Hanif Şairlerin Şiirlerine Tematik Bir Yaklaşım -Tevhid Anlayışı-

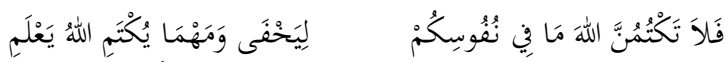

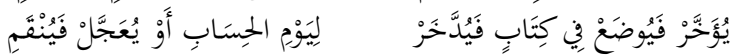

“İçinizde olan şeyleri Allah'tan gizlemeye çalışmayın. Her ne kadar gizleseniz de Allah onu bilir.

(Yaptıklarınızın karşıllğ̆ ) ertelenir ve bir kitaba konur. Ya hesap gününe saklanır ya da acele edilir ve intikam hemen alınır."

Yine Züheyr tevhid inancını gösteren işaretlerden bir tanesi de farklı kasidelerinden alınan aşağıdaki beyitlerde Allah adına yemin etmesidir:
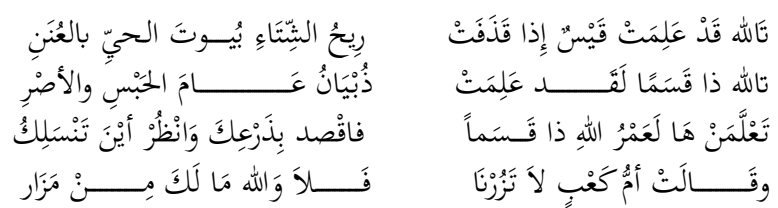

"Allah'a yemin olsun ki Kays kavmi, kış rüzgar mahallenin evlerini savurduğunda ă̆açtan yapılmış ağıllarının ne olduğunun farkına vardı. ${ }^{74}$

Allah'a yemin olsun, yeminle söylüyorum. Zübyan kavmi, hapsedildiği ve bağlandığı yılı bildi. ${ }^{75}$

Şunu iyi bil ki; Allah'a yeminle söylüyorum, yapmayacağın işi bırak, işin sonu nereye gider düşün. ${ }^{76}$

Ka'b'in annesi dedi ki: Bizi ziyaret etme. Hayır asla! Allah'a yemin olsun ki seni ziyaret edeceğimiz bir yer yok."

Yukarıda verilen beyitler farklı kasidelerden alınmıştır. $\mathrm{Bu}$ beyitlerde her birinde şair Allah adına yemin etmektedir. Daha önce de bahsedildiği gibi Cahiliye döneminde Allah adına yemin edilmesi yaygın bir anlayıştı. Züheyr de şiirlerinde bunu kullanmış ve bu da onda tevhid anlayışının olduğuna işarettir.

\subsection{Varaka b. Nevfel}

Varaka b. Nevfel (öl. 610 m.) Cahiliye dönemi hanif şairlerindendir. Ölüm tarihi hakkında ihtilaf vardır. ${ }^{78}$ Ziriklî (öl. 1976) miladi 611 yılında

74 Sa'leb, Şerhu şi'ri Züheyr b. Ebî Sülmâ, 99.

75 Sa'leb, Şerhu şi'ri Züheyr b. Ebî Sülmâ, 77.

76 Sa'leb, Şerhu şi'ri Züheyr b. Eb̂̂ Sülmâ, 137.

77 Sa'leb, Şerhu şi'ri Züheyr b. Eb̂̂ Sülmâ, 250.

78 Bk. Üzeyr Hüseyn Gassân, Varaka b. Nevfel Mübeşşiru'r-rasûl: Asruhu ve hayatuhu ve şi'ruh (Beyrut: Daru'l-Kutübi'1-i̇lmiyye, 1423/2002), 56-57. 
R. MEŞE / A Thematic Approach to The Poems of Hanif Poets in The Period of Jahiliyya -The Concept of oneness of God-I 217

öldüğünü ifade eder. ${ }^{79} \mathrm{~Hz}$. Hatice'nin amcasının oğlu olup beşinci kuşaktan Hz. Peygamber ile birleşmektedir. ${ }^{80}$ Varaka İncil ve diğer semavi dinlerin kitaplarını okuyan ender şahsiyetlerden olan ilim ehli biri olarak bilinir. ${ }^{81}$ İslam tarihi eserlerinde şairlik yönüne pek değinilmeyen Varaka aslında Cahiliye döneminin önemli şairlerden birisidir. ${ }^{82}$

Meşhur haniflerden olan Varaka putperestlikten etkilenmemiş tam aksine onların düşünce ve inançlarına karşı çıkmıştır. ${ }^{83}$ Cahiliye döneminde müşriklerin yaşam tarzını beğenmeyip yeni bir din arayışına girmiştir. $\mathrm{Bu}$ arayıştan sonra Hristiyanlı̆̆ seçtiği rivayetlerde mevcuttur. ${ }^{84}$ Ancak bu din üzerine ölüp ölmediği ihtilaf konusudur. ${ }^{85}$ Ayrıca bir şiirinde hanif olan Zeyd b. Amr'ın dinine tabi olduğunu ifade etmiştir. Pek çok dil bilen Varaka diyar diyar dolaşarak tevhid inancının peşine düşmüştür. ${ }^{86}$ Bunun yanında Varaka hakkında kaynaklarda fazla bilginin olmamasından dolayı bazı şarkiyatçılar Varaka'nın Hz. Peygamberi dini ve kültürel anlamda etkilediği iddiasını ortaya atmışlardır. Ancak bu spekülatif görüşlerin doğru olmadığı ortadadır. ${ }^{87}$

Varaka'nın putperestliği reddettiği, Arapların kötü alışkınlarından meyletmediği hanif ve muvahhid olduğu konusunda kaynaklarda ihtilaf yoktur. ${ }^{88}$ Bunu şiirlerine yansıtan Varaka, pek çok dinî temayı şiirlerde ele

79 Ebû Gays Muhammed Hayrüddîn Alî b. Fâris ez-Ziriklî, el-A'lâm, nşr. Dâru'l-İlmi Li'lMelâyîn (b.y.: Dâru'l-İlmi Li'l-Melâyîn, 1423/2002), 8/114.

80 Ziriklî, el-A'lâm, 8/115; Gassân, Varaka b. Nevfel Mübeşşiru'r-rasûl: Asruhu ve hayatuhu ve şi'ruh, 50 .

81 Zehrânî, Edebu'l-Hanefiyye fì Asri'l-Cahilî, 110.

82 Gassân, Varaka b. Nevfel Mübeşşiru'r-rasûl: Asruhu ve hayatuhu ve şi'ruh, 97.

83 İbn Asâkir, Târîhu Dımaşk, 63/3.

84 Zehrânî, Edebu'l-Hanefiyye fî Asri'l-Cahilî, 108-109.

85 Bünyamil Erul, "Varaka b. Nevfel”, Türkiye Diyanet Vakfi İslam Ansiklopedisi (İstanbul: TDV Vakfı Yayınları, 2012), 42/517.

86 Cevâd Alî, el-Mufassal fî târîhi'l-'Arab kable'l-İslâm, 12/77.

87 Bu konuda bk. Özcan Hıdır, "İlk Vahyin Gelişi Hadisi Bağlamında Varaka b. Nevfel'in Hz. Peygamber'e Dinî-Kültürel Etkisine Dair İddiaların Değerlendirilmesi", Marife 4/2 (Güz 2004), 27-37.

88 Bk. İbn Asâkir, Târîhu Dımaşk, 63/3; Ebu'l-Ferec İ̉nü'l-Cevzî, el-Muntazam fî târîhi'lumem ve'l-mulûk, 2/373; Cevâd Alî, el-Mufassal fi târîhi'l-'Arab kable'l-İslâm, 12/77. 
218 | R. MEŞE / Cahiliye Dönemi Hanif Şairlerin Şiirlerine Tematik Bir Yaklaşım -Tevhid Anlayışıalmıştır. ${ }^{99}$ Özellikle de tevhid konusundaki şiirlerinde Allah'ın birliğini vurgulamaktadır. Mesela aşağıdaki beyitlerde kabileleri tevhide çağırıp eşi ve benzeri olmayan Allah'a ibadet etmeye çağırırken şöyle demektedir: ${ }^{90}$
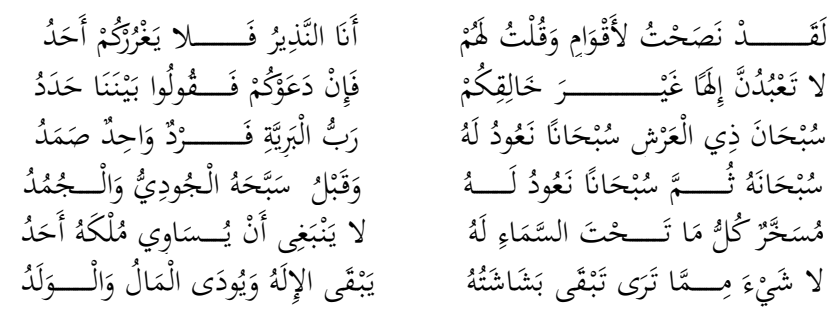

"Kabilelere nasihat ettim ve onlara şöyle dedim: Ben sadece uyarıcıyım, sizi kimse aldatmasin.

Asla yaratıcınızın başka bir Illah'a ibadet etmeyin. Ĕ̆ger sizi (başkasına ibadet etmeye) çă̆ırırlarsa, biz başkasına ibadet etmeyiz deyin.

Eşi olmayan arşın sahibini tespih ve tenzih ederim. Mahlûkatın Rabbi tektir, birdir ve sameddir.

Daha önce Cûdî ve Cumüd dağlarının tenzih ettiği gibi ben de tüm noksan sifatlardan münezzeh olana tespih eder, siğııırım.

Bu gökyüzü altında her ne varsa onun emrine amadedir. Onun mülkünde bir benzerinin olması düşünülemez.

Gördü̈̆̈̈̈n her şeyin şatafatl görünümü kalıcı değgildir. Mal ve çocukları yok olurken Allah baki kalır."

$\mathrm{Bu}$ beyitlerde Varaka bir uyarıcı olarak insanları Allah'a ibadet etmeye ve Allah'tan başkasına ibadet etmemeye çağırmıştır. Allah'ın bir, eşinin benzerinin olmadığı ve samed olduğunu vurgulamış, Allah'1 tenzih ve tespih ettiğini ifade etmiştir. Son olarak da göğün altında olan her şeyin Allah'a mülkü olduğunu ve Allah'tan başka her şeyin yok olacağını vurgulamıştır.

Mekkeli müşrikler tarafından Zeyd b. Amr öldürülünce Varaka, ona yazdığ1 mersiyede onun tevhidini şöyle tasdik etmektedir: ${ }^{11}$

89 Bu konuda bk. Gassân, Varaka b. Nevfel Mübeşşiru'r-rasûl: Asruhu ve hayatuhu ve şi'ruh, 113-154.

90 İbn Asâkir, Târîhu Dımaşk, 63/25-26; Ebu'l-Ferec İbnü'l-Cevzî, el-Muntazam fî târîhi'lumem ve'l-mulûk, 3/373-374; Gassân, Varaka b. Nevfel Mübeşşiru'r-rasûl: Asruhu ve hayatuhu ve şi'ruh, 132.

91 Gassân, Varaka b. Nevfel Mübeşşiru'r-rasûl: Asruhu ve hayatuhu ve şi'ruh, 151-152. 
R. MEŞE / A Thematic Approach to The Poems of Hanif Poets in The Period of Jahiliyya

-The Concept of oneness of God-I 219

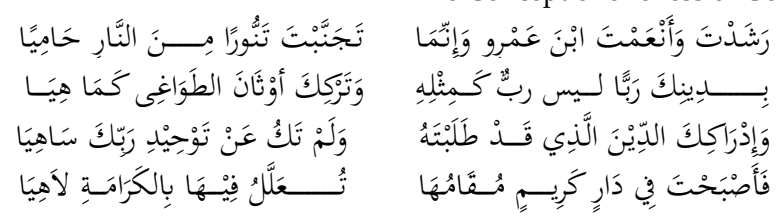

"Ey İbn 'Amr doğru yolu bularak ve yaşayarak Allah'ın o kızgin firınının ateşinden kendini korumuş oldun.

Benzeri olmayan rabbine itaat etmen ve putlar olduğu gibi terk etmen (seni ateşten korudu).

Ve istediğgin (hanif) dine ulaşman sebebiyle rabbinin tevhidinde hiç hata yapmadin.

Artık kendisinde ikamet etmenin güzel olduğu bir yurttasin ve orada saygin bir şekilde eğlenip duracaksın."

$\mathrm{Bu}$ beyitlerde aslında Varaka Zeyd b. Amr'ın tevhid inancinı aktarırken kendisinin de tasdik ettiğini ifade etmiştir. Nitekim aynı kasidenin devamında söylediği beyitlerde kendi tevhid inancını da ifade etmiştir: ${ }^{2}$
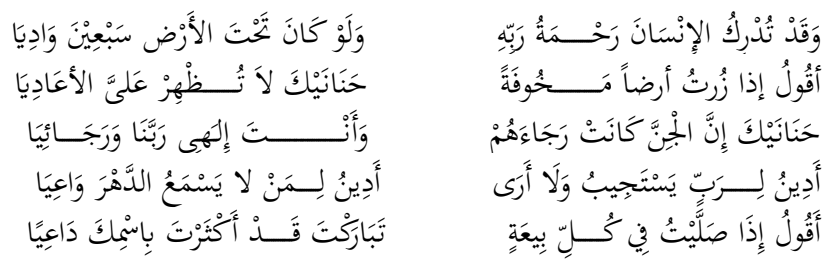

"Yerin yedi kat dibinde dahi olsa dahi insana rabbinin rahmeti ona yetişir.

Ĕger (kimsenin gitmeye cesaret edemediği) korkunç bir yere gidersem, Sana (Allah'a) sı̆̆ınırım karşıma düşmanlarımı çıkarma.

Merhametini diliyorum! Müşriklerin ricası cinleredir. Rabbim! Sen benim ilahımsın, benim ricam sanadır.

Ben duaya icabet eden rabbe ibadet ediyorum. Duymayan ve zamanin farkında olmayan şeye ibadet etmem.

Diyorum ki: Rabbim! Her mescitte sana ibadet edildiğinde yarattı̆̆ın birçok kişi ismini yüceltir."

Varaka'nın Zeyd b. Amr için yazdığı bu mersiye onun bir olan Allah'a iman ettiğini açıkça ortaya koymaktadır. Kişinin sadece rabbinin

92 Gassân, Varaka b. Nevfel Mübeşşiru'r-rasûl: Asruhu ve hayatuhu ve şi'ruh, 152-154. 
rahmetini ummasını, duymayan ve hiçbir şeyin farkında olmayan putlara ibadet etmenin anlamsızlığını bu beyitlerde ifade etmiştir.

\section{5. Ümeyye b. Ebi's-Salt}

Cahiliye dönemi hanif şairlerden biri de Ümeyye b. Ebi's-Salt'tır (öl. 8/630 ?) $)^{93} \mathrm{~Hz}$. Peygamber zamanında yaşamıştır. Müslüman olmadığından bazıları tarafından Muhadram şairleri arasında sayılmaz. ${ }^{94}$ Yahudilik ve Hristiyanlık hakkındaki kitapları okumuş ve bunlara vakıf olmuştur. ${ }^{95}$ Putperestlikten uzak durmuş, Cahiliyenin yaşama tarzına karşı çıkmış ve hanif dinini benimsemiştir. Cahiliye döneminde kullanılan "Bismikellahümme" ifadesinin ilk kullanımı ona nispet edilir. ${ }^{96}$

Ümeyye bir peygamberin gönderileceğini biliyordu. Ancak bu şerefin kendisine verileceğini zannediyordu. ${ }^{97}$ Risalet görevi $\mathrm{Hz}$. Peygamber'e verildiğinde ona inandığ 1 kıskançlık duygusundan Müslüman olmamıştır. ${ }^{8} \mathrm{~Hz}$. Peygamberi üzen davranışlar göstermiş ve bedir ölüleri için de mersiye söylemiştir. ${ }^{99}$

Ümeyye, Cahiliye dönemi şairleri arasında divanında dini meselelerin en çok olduğu şairdir. Bu şairin divanı tevhid, Allah'a övgü, ölümden sonra diriliş, hesap ve ceza gibi hakikatler yoğunluktadır. ${ }^{100}$ Ancak bu şairin şiirleri her ne kadar hakikatleri ikrar etse de kalbi iman etmemiş, İslam geldikten sonra Müslümanlara karşı düşmanca bir tavra girmiştir. Bu sebeple Peygamber efendimiz onunla ilgili olarak "dili iman etti kalbi inkâr etti" buyurmuştur. ${ }^{101} \mathrm{~Hz}$. Peygamber'in bu şekilde

93 Bu konuda bk. Ebu'l-Ferec İbnü'l-Cevzî, el-Muntazam fî târîhi'l-umem ve'l-mulûk, 3/142151.

94 Zülfikar Tüccar, "Ümeyye b. Ebü's-Salt”, Türkiye Diyanet Vakfı İslam Ansiklopedisi (İstanbul: TDV Yayınları, 2012), 42/304.

95 Behcet Abdulğafûr el-Hadîsî, Ümeyye b. Ebi's-Salt Hayâtuhî ve şi'ruhu (Abû Dabi: Mecmaü's-Sekâfî, 1430/2009), 49.

96 İbn Kesîr, el-Bidâye ve'n-nihâye, 2/286. Küçükçopur, İslam Tarihinde Hanifler, 62.

97 Küçükçopur, İslam Tarihinde Hanifler, 62.

98 Ebu'l-Ferec İbnü'l-Cevzî, el-Muntazam fî târîhi'l-umem ve'l-mulûk, 3/142; Dayf, Târîhu'ledebi'l-Arabî, 1/394.

99 İbn Kesîr, el-Bidâye ve'n-nihâye, 3/413.

100 Bu konuda bk. Dîvânu Ümeyye b. Ebi's-Salt, thk. Beşîr Yemût (Beyrut: Mataba'atü'lVataniyye, 1934), 17-74.

101 Ebu'l-Ferec İbnü'l-Cevzî, el-Muntazam fî târîhi'l-umem ve'l-mulûk, 3/142. 
R. MEŞE / A Thematic Approach to The Poems of Hanif Poets in The Period of Jahiliyya -The Concept of oneness of God-I 221 buyurmasına sebep olan ve zahiren Ümeyye'nin din anlayışını ortaya koyan beyitlerden bir k1smı şöyledir: ${ }^{102}$

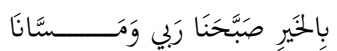

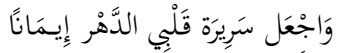

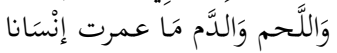

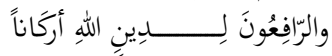

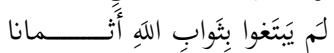

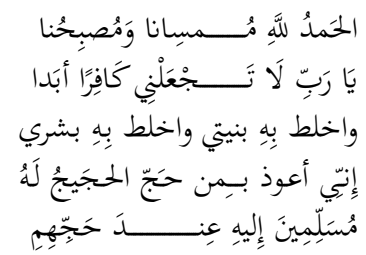

"Bizi en güzel şekilde sabaha ve akşama kavuşturan rabbim Allah'a hamd olsun.

Ey Rabbim! Beni asla kafir kılma ve kalbimin derinliğine imanı yerleştir.

Bir insan olarak yaşadığım sürece imanı bünyeme, derime, etime, kanıma karıştır.

Ben kendisi için hacıların hac yaptı̆̆ına ve Allah'ın dininin erkânlarımı yüceltenlerin hac yaptı̆̆ına sĭ̆ııırım.

Onlar ki hac yaparken Allah'a teslim olurlar ve O'nun sevabından başka bir şey istemezler."

Bu beyitlerde Ümeyye'nin din anlayışı İslam'a çok yaklaşmaktadır. Zira Allah'a hamd ile başlamaktadır. Daha sonra rabbinden iman dilemekte ve imanın bütün zerrelerine yerleşmesi için dua etmektedir. Çok eskiden beri var olan hac ibadetinin de sadece Allah için yaptığını vurgulamaktadır. Tevhid vurgusunun çok bariz olduğu bu beyitlerde her ne kadar içerik doğru olsa da söylenirken samimiyet olmadiğından $\mathrm{Hz}$. Peygamber Ümeyye' nin kalbinin iman etmediğini buyurmuştur.

Bir başka kasidesinin ilk iki beytinde Ümeyye Allah’ın birliğini şu beyitlerle vurgulamıştır: ${ }^{103}$

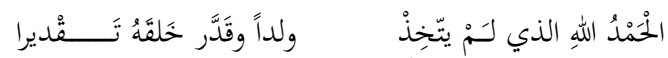

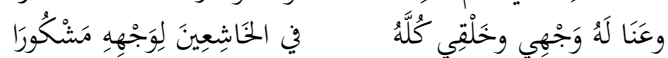

“Çocuk edinmeyen ve bütün varlıklara bir kader tayin eden Allah'a hamd olsun.

Allah'a şükrederek boyun eğenlerle içinde ben de bütün benliğim ve yaratılışımla ona boyun eğerim."

\footnotetext{
102 Dîvânu Ümeyye b. Ebi's-Salt, 62.

103 el-Hadîsî, Ümeyye b. Ebi's-Salt Hayâtuhû ve şi'ruhu, 206-207.
} 
Yine bu beyitlerde Ümeyye Allah birliğini ve her şeye takdir ettiğini ifade ederek kendisinin bütün benliği ile O'na yöneldiğini vurgulamıştır.

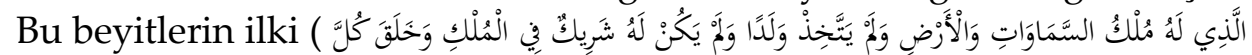

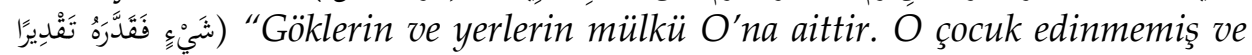
mülkünde ortağı yoktur. Her şeyi bir ölçüye göre takdir ederek yaratmıştır."

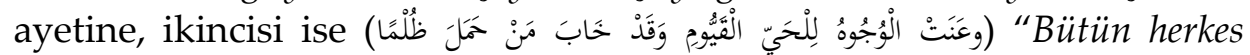
yaşayan, yaratıklarına hakim olan ve onları koruyup gözeten Allah'a boyun eğer. Zulüm yüklenen kaybetmiştir"105 ayetine muhteva ve lafız açısından benzemektedir. Ümeyye'nin divanı incelendiğinde ise birçok şiirinin muhteva ve lafızları Kur'ân'la benzerlik gösterdiği görülebilir. Bu durum bu şiirlerin sonradan Müslümanlar tarafından ona nispet edildiği iddiasını ortaya çıkarmıştır. Ancak Cevâd Ali gibi tarihçiler onun şiirlerinin Kur'an'dan iktibas olmasına ihtimal vermemektedir. Cevad Ali birçok ihtimal üzerinde durduktan sonra Ümeyye'nin şiirlerinde Kur'ân lafızlarını ve muhtevasının olmasının sebebini İslamî dönemde bazılarının yaptı̆̆ı bir işe bağlayıp bu ifadelerin Ümeyye'nin dilinden söylendiğini ifade etmiştir. ${ }^{106}$

Bir başka şiirinde Ümeyye âlemlerin rabbinin Allah olduğunu ve yeri ve göğü yaratmasını, kâinatı oluşumunu şöyle tasvir etmektedir:107
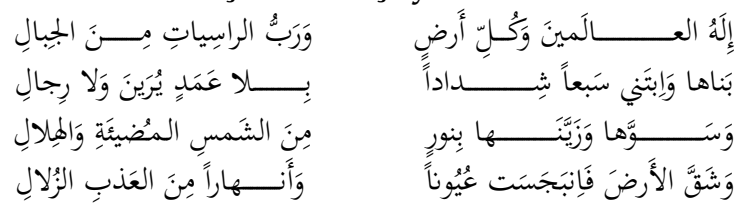

"(Allah) âlemlerin ve bütün yerin ilahıdır. Yeryüzünde sabit, büyük dağların rabbidir.

Yeri inşa etti ve gözle görülebilecek ne bir direk ve bir adam olmadan yedi kat göğ ü yarattı.

O yere şekil verdi. Parlak güneş ve hilalin ışığıyla da onu süsledi.

Yer yarıldı. Tatll, saf pinar ve nehir suları ortaya çıktı."

Bu beyitlerde Ümeyye'nin yerin ve göğün yaratmasından, kâinatın oluşumdan bahsetmesi Allah'ın birliğine delil getirmesinden

\footnotetext{
104 el-Furkân 25/2.

105 Taha 20/111.

106 Cevâd Alî, el-Mufassal fî târîhi'l-'Arab kable'l-İslâm, 12/66-68.

107 Dîvânu Ümeyye b. Ebi's-Salt, 49; Dayf, Târîhu'l-edebi'l-Arabî, 1/394.
} 
R. MEŞE / A Thematic Approach to The Poems of Hanif Poets in The Period of Jahiliyya

-The Concept of oneness of God-I 223

kaynaklanır. Ümeyye, divanında Allah'ın varlı̆̆ı ve birliğine işaret eden delilleri sık sık kullanir.

Yukarıda verdiğimiz şiirler dışında tevhidi konu edindiği şiirleri divanında mevcuttur. Ümeyye' nin bu şiirlerde güçlü bir tevhid vurgusu vardır. Verilen örnekler konunun anlaşılması için yeterli olacağından bu örneklerle yetinilmiştir.

\section{Sonuç}

İslam tarihi açısından haniflerin özelde ise hanif şairlerin yaşantı ve düşüncelerinin ve bunların şiirlerine yansımalarının bilinmesi önemlidir. Öyle ki oryantalistler haniflik olarak bilinen anlayışın İslam ile beraber ortaya çıktığı iddialarına karşın, Ümeyye b. Salt'ın bi'setten önce haniflik ibaresini şiirlerinde kullanması oryantalistlerin tezini çürütmede önemli bir delildir. Bu açıdan bu çalışmada Cahiliye döneminde meşhur olan hanif şairlerin şiirlerinde tevhid anlayışları ortaya konulmuştur. Söz konusu hanif şairlerin şiirlerinin sıhhati konusunda şüpheye düşenlerin delillerinin de tatmin eder derece olmadığı aşikârdır. Bu açıdan Cahiliye döneminde tevhid ile alakalı yazılan bu şiirlerin o dönemde tevhid inancına sahip kişilerin varlığını ortaya koymakla beraber bu inancın nasıl olduğuna dair bilgi de vermektedir.

$\mathrm{Bu}$ şiirlerin mütalaası neticesinde çalışmada ele alınan hanif şairlerin tevhid anlayışı ile İslam'ın tevhid anlayışı arasında herhangi bir fark görülmemiştir. Hanif şairlerin İslam inanç sistemi ile paralel bir anlayışta oldukları ve İslam inanç ve muamelat sistemine aykırı bir davranış sergilemedikleri bu şiirlerden anlaşılabilir. Zira Allah'ın birliği, O'na ortak koşmanın yanlışlığı, O'nun yerin ve göğün sahibi olduğu, bütün mahlûkatın tek sahibi ve yaratıcısı, din ve hesap günün sahibi olduğu gibi İslam'ın temel tevhid vurgusu bu şiirlerde de dile getirilmiştir. Söz konusu şairlerin yeni bir peygamber bekledikleri ve bunu bazı şiirlerinde dile getirdikleri de bilinir. Yeni peygambere de bu hanif şairlerin bazıları inanmış, bazıları inanmamış, bazıları ise iman etmeye ömürleri vefa etmemiştir. Ümeyye b. Ebi's-Salt ise yeni peygamberi kabullendiği halde iman etmemiştir. 
224 | R. MEŞE / Cahiliye Dönemi Hanif Şairlerin Şiirlerine Tematik Bir Yaklaşım -Tevhid Anlayışı-

\section{Kaynakça}

Brockelmann, Carl. Târîhu'l-edebi'l-Arabî. çev. Abdulhalim en-Neccâr. 6 Cilt. Kahire: Dâru'l-Meârif, 4. Basım, ts.

Câhiz, Ebû Osmân Bahr b. Mahbûb. el-Beyân ve't-Tebyîn. 3 Cilt. nşr. Daru'l-Kütübi'l-İlmiyye. Beyrut: Daru'l-Kütübi'l-İlmiyye, $1423 / 2002$.

Cevâd Alî. el-Mufassal fi târîhi'l-'Arab kable'l-İslâm. 20 Cilt. b.y.: Dâru'sSâkî, 4. Basım, 1422/2001.

Cevherî, Ebû Nasr İsmail b. Hammâd. Tâcu'l-lüğa ve sihâhu'l-Arabiyye. thk. Ahmed Abdulgafûr Attâr. 6 Cilt. Beyrut: Dâru'l-İlmî Li'l-Melâyîn, 4. Basım, 1407/1987.

Cumahî, Ebû Abdillâh Muhammed b. Sellâm. Tabakâti fuhûli'ş-şuâra. thk. Mahmud Muhammed Şâkir. 2 Cilt. Cidde: Dâru'l-Medenî, ts.

Cündî, Alî. Fî târîhi'l-Edebi'l-Câhilî. b.y.: Mektebetü Dâru't-Türâs, 1412/1991.

Çağrıcı, Mustafa. "Arap". Türkiye Diyanet Vakfı İslam Ansiklopedisi. 3/316321. İstanbul: TDV Yayınları, 1991.

Dayf, Şevkî. Târîhu'l-edebi'l-Arabî. 10 Cilt. Misır: Dâru'l-Me'ârif, 1995.

Demirayak Kenan - Çöğenli, Sadi. Arap Edebiyatında Kaynaklar. Erzurum: Atatürk Üniversitesi Fen-Edebiyat Fakültesi Yayınları, 1994.

Dîvânu Ümeyye b. Ebi's-Salt. thk. Beşîr Yemût. Beyrut: Mataba'atü'1Vataniyye, 1352/1934.

Dîvânu Evs b. Hacer. thk. Muhammed Yûsuf Necm. Beyrut: Dâru'l-Beyrût, $1400 / 1980$.

Ebû Hilâl el-'Askerî, el-Hasen b. Abdillâh b. Sehl. el-Evâil. nşr. Dâru'lBeşîr. Tanta: Dâru'l-Beşîr, 1408/1987.

Ebû Zeyd el-Kurâşî, Muhammed b. Ebi'l-Hattâb. Cemheretü eş âri'l-Arab. thk. Alî Muhammed el-Becâdî. b.y.: Nahdatü Misr Li'-tibâ'a ve'nNeşr ve't-Tevzî̀ $\hat{i}^{\prime}$ ts.

Ebu'l-Ferec İbnü'l-Cevzî, Cemâluddîn. el-Muntazam fí târîhi'l-umem ve'lmulûk. thk. Muhammed Abdulkadir Atâ - Mustafa Abdulkadir Atâ. 19 Cilt. Beyrut: Dâru'1-Kütübi'1-İlmiyye, 1412/1992.

Erul, Bünyamil. "Varaka b. Nevfel". Türkiye Diyanet Vakfi İslam Ansiklopedisi. 42/517-518. İstanbul: TDV Vakf1 Yayınları, 2012.

Erkocaaslan, Recep. "Haniflerden Zeyd b. Amr. Nüfeyl'in Hayatı ve Şahsiyeti". Amasya İlahiyat Dergisi. 15 (Aralık 2020), 421-451. 
R. MEŞE / A Thematic Approach to The Poems of Hanif Poets in The Period of Jahiliyya -The Concept of oneness of God-I 225

Fayda, Mustafa. "Cahiliye”. Türkiye Diyanet Vakfi İslam Ansiklopedisi. 7/1719. İstanbul: TDV Yayınları, 1993.

Ferâhîdî, Halîl b. Ahmed. Kitâbu'l-'ayn. thk. Mehdî el-Mahzûmî - İbrahim es-Samirrâî. 8 Cilt. Dâru ve Mektebetü'l-Hilâl, ts.

Gassân, Üzeyr Hüseyn. Varaka b. Nevfel Mübeşşiru'r-rasûl: Asruhu ve hayatuhu ve şi'ruh. Beyrut: Daru'l-Kütübi'l-İlmiyye, 1423/2002.

Hadîsî, Behcet Abdulğafûr. Ümeyye b. Ebi's-Salt Hayâtuhû ve şi'ruhu. Abû Dabi: Mecmaü's-Sekâfî, 1430/2009.

Hıdır, Özcan. “İlk Vahyin Gelişi Hadisi Bağlamında Varaka b. Nevfel’in Hz. Peygamber'e Dinî-Kültürel Etkisine Dair İddiaların Değerlendirilmesi". Marife 4/2 (Güz 2004), 27-37.

Hüseyn. Taha. Cahiliye Şiiri Üzerine. çev. Şaban Karataş. Ankara: Ankara Okulu Yayınları, 2. Basım, 2003.

İbn Asâkir, Ebü'l-Kâsım Alî b. el-Hasen b. Hibetillâh. Târîhu Dımaşk. thk. 'Amr b. Ğarâme el-Ümeyrî. 80 Cilt. b.y.: Dâru'l-Fikr, 1415/1995.

İbn Dureyd, Ebû Muhammed b. Hasan el-Ezdî. Cemheretü'l-lüğa. thk. Remzî Münîr Ba'lebekî. 3 Cilt. Beyrut: Dâru'l-İlmî Li'l-Melâyîn, 1407/1987.

İbn Hişam, Ebû Muhammed Cemâlüddîn Abdülmelik el-Meâfirî. esSîretü'n-nebeviyye. thk. Mustafa es-Sekkâ vd.. 2. Cilt. Kahire: Şirketü ve Matbatü Mustafa, 2. Basım. 1375/1955.

İbn Hişâm, Ebû Muhammed Cemâlüddîn Abdülmelik el-Meâfirî. et-Tîcân fî mülûki Himyer. thk. Merkezü'd-Dirâsât ve'l-Ebhâsı'l-Yemeniyye. San'â: Merkezü'd-Dirâsât ve'l-Ebhâsı'l-Yemeniyye, 1347/1928.

İbn İshâk, Ebû Abdillâh Muhammed b. el-Muttalibî. Sîretü İbn İshâk. thk. Sühey Zekkâr. Beyrut: Dâru'l-Fikr, 1398/1978.

İbn Kesîr, Ebü'l-Fidâ' İmâdüddîn el-Kaysî el-Kureşî. el-Bidâye ve'n-nihâye. thk. Alî Şîrî. 14 Cilt. Beyrut: Dâru İhyâi't-Türâsi'l-Arabî, 1408/1988.

İbn Kuteybe, Ebû Muhammed Abdullah b. Müslim ed-Dîneverî. eș-Şi 'ru ve'ş-Şu 'arâ. nşr. Dâru'1-Hadîs. 2 Cilt. Dâru'l-Hadîs. Kahire: Dâru'1Hadîs, 1453/2002.

İbn Manzûr, Muhammed b. Mukerrem Cemâluddin. Lisânu'l- 'Arab. nşr. Dâru Sâdır. 15 Cilt. Beyrût: Dâru Sâdır, 3. Basım, 1414/1993. 
226 | R. MEŞE / Cahiliye Dönemi Hanif Şairlerin Şiirlerine Tematik Bir Yaklaşım -Tevhid Anlayışı-

İbnü'l-Cevzî, Ebü'l-Muzaffer Şemsüddîn Yûsuf b. Kizoğlu Sibt. Mir 'âtü'zzamân fî̀ târîhi'l-a'yân. 23 Cilt. thk. Muhammmed Berakat vd.. Dımeşk: Dâru'r-Risâleti'l-Alemiyye, 1434/2013.

İbnü'l-Esîr, Ebü'l-Hasen İzzüddîn eş-Şeybânî el-Cezerî. Üsdü'l-ğâabe fî ma'rifeti's-sahâbe. thk. Alî Muhammed Mu'avved - Adil Ahmed Abdulmevcûd. 8 Cilt. Beyrut: Dâru'l-Kütübi'l-i̇lmiyye, 1415/1994.

İmruü'l-Kays, Hucr b. el-Hâris el-Kindî. Divânu İmrü̈'l-Kays. thk. Abdurrahman Mustâvî. Beyrut: Dâru'l-Ma'rife, 2 Basım, 1425/2004. Kapar, Mehmet Ali. "Kus. b. Sâ'ide". Türkiye Diyanet Vakfı İslam Ansiklopedisi. 26/460. Ankara: TDV Yayınlar, 2002.

Kaplan, Hasan. "Bir İnanç Aşaması Olarak Haniflik". Çanakkale Onsekiz Mart Üniversitesi İlahiyat Fakültesi Dergisi 1/10 (2017), 7-23.

Kaysî, Eysem Abbâs. "Zeyd b. Amr b. Nufeyl Hayâtuh ve mâ Tebkâ min Şi'rih". Mecelletu'l-Meorid 29/4, 87-94.

Kuzgun, Şaban. "Hanîf". Türkiye Diyanet vakfı İslam Ansiklopedisi. 16/3339. İstanbul: TDV Yayınları, 1997.

Küçükçopur, Hasan. İslam Tarihinde Hanifler. Konya: Selçuk Üniversitesi, Sosyal Bilimler Enstitüsü, Yüksek Lisans Tezi, 1988.

Muhtar, Cemal. “Cahiliye Devri Şiiri”. Doğu Dilleri [Ankara Üniversitesi Dil ve Tarih-Coğrafya Fakültesi Doğu Dilleri ve Edebiyatları Bölümü Dergisi] 1/1 (1964), 47.

Mus'tasımî, Muhammed b. Aydemir. ed-Dürrü'l-ferîd ve beytü'l-kasîd. thk. Kâmil Selmân el-Cebûrî. 13 Cilt. Beyrut: Dâru'l-Kütübi'l-İlmiyye, 1436/2015.

Özkan, Halit. "Zeyd b. Amr”. Türkiye Diyanet Vakfı İslam Ansiklopedisi. 44/316-317. İstanbul: TDV Yayınlar, 2013.

Polat, İbrahim Ethem. "Hanif Şairlerin Şiirlerinde Monoteist Yapı". Nüsha: Şarkiyat Araştırmaları Dergisi 1/1 (Bahar 2001), 124-133.

Sa'leb, Ebu'l-Abbâs. Şerhu şi'ri Züheyr b. Ebî Sülmâ. thk. Fahreddîn Kabâve (Dımeşk: Matba'atü'l-Ğûsânî, 3. Basım, 2008.

Söylemez, Mehmet Mahfuz. "Fil Hadisesinin Arap Yarımadasındaki Etkileri Üzerine Bir İnceleme”". çev. Fuat Aydın. Kuran'daki Hanîfller ve Nasârâ Üzerine Araştırmalar. Ankara: Eskiyeni Yayınları, 2016.

Şentemerî, Ebü'l-Haccâc Yûsuf b. Süleymân b. Îsâ el-A'lem en-Nahvî. Şerhu Dîvâni Zuheyr b. Ebî Sulmâ. thk. Muhammed Bedruddin Ebî Firâs. Misır: Matbaatü'1- Hamidiyye, 1323/1905. 
R. MEŞE / A Thematic Approach to The Poems of Hanif Poets in The Period of Jahiliyya -The Concept of oneness of God-I 227

Şeyho, Luvis. Şuarâu'n-nasrâniyye kable'l-İslâm. Beyrut: Dâru'l-Meşrik, 4. Basım, 1991.

Şüreysî, Ebû Abbas Ahmed b. Abdulmü'min. Şerhu makâmatı'l-Harîrî. 3 Cilt. Beyrut: Dâru'1-Kütübi'l-İlmiyye, 2. Basım, 1427/2006.

Tüccar, Zülfikar. "Ümeyye b. Ebü's-Salt". Türkiye Diyanet Vakfi Íslam Ansiklopedisi. 42/303-305. İstanbul: TDV Yayınları, 2012,

Tülücü, Süleyman. “Cahiliye Devri Şairlerden Züheyr'in Dini İnancı ve Şiirlerinde Dini İzler". Diyanet Dergisi 25/2 (1989), 3-12.

Tülücü, Süleyman. "Züheyr b. Ebî Sülmâ". Türkiye Diyanet Vakfı İslam Ansiklopedisi. 44/540-542. İstanbul: TDV Yayınları, 2013.

Yalar, Mehmet. “Din Faktörü Işında Cahiliye Şiirine Bir Bakış”. Uludă̆ Üniversitesi İlahiyat Fakültesi Dergisi 15/2 (2006), 19-43.

Zebîdî, Muhammed b. 'Abdurrezzâk el-Hüseynî Ebü'l-Feyd. Tâcu'l-arûs min cevâhiri'l-kâmûs. thk. Mecmu'atün mine'l-Muhakkîkin. 40 Cilt. b.y.: Dâru'l-Hidâye, ts.

Zehebî, Ebû Abdillâh Şemsüddîn Muhammed b. Ahmed b. Osmân. Târihü'l-İslam ve vefeyâtü'l-meşâhiri'l-a'lâm. thk. Beşşâr Avvâd Ma'rûf. 15 Cilt. b.y.: Dâru'l-Ğarbi'l-İslâmî, 1424/2003.

Zehrânî, Hamdân. Edebu'l-Hanefiyye fî Asri'l-Câhilî. Mekke: Câmiatu Ümmi'1-Kurâ, Kulliyeti Lügati'1-Arabiyye ve Âdâbıha, Doktora Tezi, 1406/1985.

Zevzenî, Ebû Abdillâh Hüseyn b. Ahmed. Şerhu'l-muallakatı's-seb 'a. nşr. Dâru İhyâi't-Türâsi'1-Arabî. b.y.: Dâru İhyâi't-Türâsi'l-Arabî, $1423 / 2002$.

Zeyyât, Ahmed Hasan. Târîhu'l-edebi'l-'Arabî. Kahire: Dâru Nahdâti Misr, 15. Basım, ts.

Ziriklî. Ebû Gays Muhammed Hayrüddîn Alî b. Fâris. el-A'lâm. nşr. Dâru'l-İlmi Li'l-Melâyîn. b.y.: Dâru'1-İlmi Li'l-Melâyîn, 5. Basım, $1423 / 2002$. 